\title{
El permiso de construcción desde la perspectiva del Derecho administrativo general. Análisis de sus principales problemas a nivel jurisprudencial
}

\section{Urban planning licenses in general administrative law. Analysis of its main problems in jurisprudence}

Esta investigación tiene por objeto analizar como el permiso de construcción en Chile se ha insertado dentro de las instituciones y categorías del Derecho administrativo, a partir de la legislación positiva y una jurisprudencia administrativa y judicial que ha reforzado una visión del Derecho urbanístico como una disciplina que pertenece a dicha rama del derecho. Por su parte, también se demuestra como dicha institución ha sido una de las principales categorías de análisis que ha permitido fortalecer el Derecho administrativo general y aportar conclusiones que se proyectan en diversos ámbitos de esta disciplina,
This research aims to analyze the urban planning license in Chile and the way it has been incorporated into the institutions and concepts of administrative law, considering positive legislation and jurisprudence from a vision of urban law. In addition, it is shown how this license constitutes one of the main categories of analysis to strengthen general administrative law and provide conclusions that are projected in various areas of this discipline, such as the existence of rights that have their source in legaladministrative titles, the effects of the invalidation, the extinction for the

\footnotetext{
* Profesor Titular de Derecho Administrativo de la Facultad de Derecho de la Pontificia Universidad Católica de Valparaíso, Chile. Doctor en Derecho y Máster en Política Territorial y Urbanística, Universidad Carlos III de Madrid. Correo electrónico: eduardo.cordero@ pucv.cl. Dirección postal: Pontificia Universidad Católica de Valparaíso, Facultad de Derecho, Avenida Brasil 2950, Valparaíso, Chile. Este trabajo es parte de dos proyectos de investigación financiados por FONDECYT sobre "La potestad de autorización administrativa: fundamentos dogmáticos, régimen y problemas en el ordenamiento jurídico chileno", $N^{\circ} 118159$, en el que el autor es coinvestigador, y el proyecto "Criterios y estándares para el control de la potestad sancionadora de la Administración: análisis de los mecanismos de revisión judicial y administrativa" No 1201868, en la cual es investigador responsable.
}

Artículo recibido el 26 de marzo de 2021 y aceptado el 12 de junio de 2021. 
como es la existencia de derechos que tienen su fuente en títulos jurídico-administrativos, los efectos de la invalidación, la institución de la caducidad y los mecanismos de impugnación.

Palabras claves: Permiso, Construcción, Urbanismo. term and the judicial and administrative actions.

Keywords: Urban planning licenses, Construction, Urbanism.

\section{Introducción}

La posibilidad de construir una disciplina jurídica está sujeta a la existencia determinadas instituciones que permitan crear un sistema que tiene elementos de identidad respecto de otras, aunque aquello no signifique necesariamente su total autonomía, ya sea porque se debe trabajar sobre el mismo dato positivo o, en su caso, porque hay instituciones, conceptos y categorías que están consolidadas y que deben ser aceptados como un elemento que condiciona y colabora en toda construcción dogmática. No obstante, aquello no obsta que desde la especialidad de cada disciplina se pueda plantear una revisión de estas categorías y conceptos generales que se han ido asentando con el tiempo.

Esto es lo que ha ocurrido en la relación entre el Derecho administrativo general y el Derecho urbanístico. Ambas son disciplinas que se fueron construyendo de forma independiente en nuestro ordenamiento, pero que de forma paulatina han llegado a un punto de confluencia en donde el análisis y revisión de las instituciones urbanísticas ha significado un importante aporte respecto de los planteamientos de los conceptos jurídico-administrativos de la parte general'. Así, se produce un proceso de "ida y retorno", que permite el estudio de las instituciones del Derecho urbanístico con los instrumentos del Derecho administrativo general (método deductivo), para luego plantear una revisión desde lo particular a lo general (método inductivo), con un fuerte componente propio de la tópica, que lleva a que el razonamiento jurídico no sea meramente deductivo y que el derecho se configure como un sistema abierto, en la medida que los conceptos jurídicos están en constante construcción a partir de los casos $^{2}$.

Este planteamiento es que el que se quiere demostrar a partir de la revisión de una de las instituciones centrales del Derecho urbanístico, como es la autorización o la licencia urbanística, y que en nuestra legislación se le denomina "permiso de construcción" ${ }^{3}$. En tal sentido, nuestra hipótesis de trabajo

\footnotetext{
1 Cordero 2015, 92-138.

2 Atienza 2005, 31.

${ }^{3}$ Esto concepto es de carácter general, pues comprende todas las obras de edificación y urbanización. Por lo tanto, los permisos de edificación o de urbanización son una especie del permiso de construcción, tal como se desprende del artículo 116 de la LGUC y de los artículos 1.4.1, 1.4.15 y 1.4.20 de la OGUC. En el mismo sentido, RaJevic 2004, 185.
} 
es que el permiso de construcción en Chile se ha insertado dentro de las instituciones y categorías del Derecho administrativo, a partir de una legislación positiva y una jurisprudencia administrativa y judicial que ha reforzado una visión del Derecho urbanístico como una disciplina que pertenece a dicha rama del derecho. Por su parte, también ha constituido una de las principales categorías de análisis que ha permitido fortalecer el Derecho administrativo general y aportar conclusiones que se proyectan en diversos ámbitos de esta disciplina, a partir de casos concretos que, siendo semejantes, permiten proyectar una regla de derecho no solo para las soluciones futuras, sino también para la parte general de la disciplina, como se intentará demostrar en este trabajo.

\section{El permiso de construcción desde el Derecho administrativo general}

El permiso de construcción constituye una de las instituciones centrales del Derecho urbanístico, pues representa el punto de encuentro entre las decisiones de política pública en materia de ordenación del territorio, a través de los instrumentos de planificación, y el ejercicio del ius aedificandi que se ejerce una vez que se ha determinado el contenido material del derecho de propiedad 4 . En buena medida, el régimen urbanístico de la propiedad se materializa a través de un control previo de la autoridad que cumple con todas las características propias de las técnicas de la autorización, mediante la cual se levanta una prohibición general para edificar, aunque sujeto a un marco regulatorio en los términos previstos en el permiso de construcción o la licencia urbanística.

La introducción de esta institución en nuestro ordenamiento ha sido de forma paulatina a partir de la última parte del siglo XIX, hasta que se consolida en la legislación municipal de 1915 y, luego, con la primera ley general de construcciones y urbanización de $1931^{5}$. Sin embargo, desde el punto dog-

\footnotetext{
${ }^{4}$ Este contenido que es determinado por la autoridad no solo establece la edificabilidad y el uso del suelo, sino también su proyección en el plano vertical y horizontal a través de diversas normas sobre alturas, coeficiente de ocupación o distanciamientos, entre otras. Véase PAREJO 1996, 387-402.

${ }^{5}$ En los albores de nuestra legislación urbanística de origen decimonónico, se establece por primera vez un control previo en la edificación que consistía en la aprobación municipal de los planos y especificaciones conforme a la "Lei sobre Transformación de la ciudad de Valparaíso" de 11 de diciembre de 1876 (artículo 11). Aquello se consolida con la "Lei № 2.203", de 7 de septiembre de 1909, que fija las disposiciones a que deberá sujetarse la construcción de edificios, apertura, ensanche, unión, prolongación o rectificación de calles de la ciudad de Santiago, estableciendo de forma expresa que "En la ciudad de Santiago nadie podrá edificar sin que previamente la autoridad municipal haya fijado la línea de la vía pública correspondiente al exterior del edificio" (artículo 6), lo que posteriormente se replica en la "Lei № 2.196 de 17 de setiembre de 1909, sobre la Transformación de la ciudad de Talca" para edificar y reconstruir edificios en los costados de las calles, plazas y otros bienes nacionales de uso público (artículos 1 y 5); en la "Lei № 2.297 de 9 de marzo de 1910, sobre la Transformación i reconstrucción de la ciudad de Valdivia" (artículo 6), y la "Lei número 2.658 de 13 de junio de 1912, sobre la Construcción de edificios i la apertura, ensanche, unión, prolongación o rectificación de calles, avenidas i plazas en la ciudad de Concepción" (artículos 3, 4 y 20). Con carácter general, fue establecida en la Ley
} 
mático su tratamiento no fue asumido a partir de los conceptos del Derecho administrativo general, hasta que lentamente se produce un proceso de integración, iniciado por la jurisprudencia administrativa y que luego se consolida con la entrada en vigor de la Ley $N^{\circ} 19.880$, sobre base de los procedimientos que rigen a los órganos de la Administración del Estado, de 2003 (LBPA), que permite insertar las instituciones propias del Derecho y la legislación urbanística con la legislación administrativa general, unida a los conceptos y categorías desarrolladas por la dogmática y la jurisprudencia. Así, los principales problemas del Derecho urbanístico comienzan a ser tratados por la jurisprudencia desde la lógica del Derecho administrativo.

Ahora bien, en dicho contexto el permiso de construcción es estudiado conforme a las categorías y distinciones realizadas desde la parte general del Derecho administrativo, particularmente en una doble perspectiva: Desde un punto de vista formal, se le considera dentro de las actuaciones que producen efectos jurídicos, dentro de las cuales destaca el acto administrativo; mientras que, desde un punto de vista substancial, se atiende al tipo de actividad o función que cumplen los servicios públicos, en la cual se inserta la técnica de la autorización ${ }^{6}$.

En la actualidad no se discute que el permiso de construcción constituye un acto administrativo, pues reúne todos los elementos propios de este tipo de actuaciones. Así, por lo demás, lo había reconocido la jurisprudencia ${ }^{7}$ y

$\mathrm{N}^{\circ}$ 2.960, de 23 de enero de 1915, que reforma la Ley Orgánica de Municipalidades, disponiendo que "No se podrá proceder a la formación de nuevos barrios dentro de los límites urbanos de las ciudades, por medio de la división de propiedades i de su venta en sitios, sin que los interesados hayan sometido previamente a la aprobación de la Municipalidad el plano respectivo, en el cual se determinará la ubicación i dimensiones de las vías i plazas que se propongan formar" (artículos $25 \mathrm{~N}^{\circ}$ 1). Posteriormente se recogerá dicha regla en la Ley $\mathrm{N}^{\circ} 4.563$, de 14 de febrero de 1929, sobre construcciones antisísmicas, antecedente directo de nuestra Ley General de Urbanismos y Construcciones, estableciendo el permiso municipal previo para poder construir en las localidades de más de 5.000 habitantes. Se establece que nadie puede "construir, reconstruir ni efectuar reparaciones o transformaciones de importancia, sin permiso de la autoridad comunal [...] en las grandes construcciones o en las de naturaleza especial, la autoridad local podrá exigir que, junto con los planos y especificaciones, se le presenten los cálculos de estabilidad". Por último, la Ley General sobre Construcciones y Urbanización aprobada mediante el Decreto con Fuerza de Ley $\mathrm{N}^{\circ} 4.882$, de 6 de febrero de 1936, establece sin distinción que "No se podrá construir, reconstruir, ni efectuar reparaciones en un edificio, sin permiso de la Dirección de Obras Municipales" (artículo $8^{\circ}$ ). Si bien su texto original fue aprobado por el DFL N 345 , de 30 de mayo de 1931, se prorrogó su entrada en vigencia hasta el 6 de febrero de 1936. Véase CORDERO 2017, 127-152.

${ }^{6}$ Esta es una distinción tradicional adoptada por el Derecho administrativo, en la cual se distingue entre aquella actuación que está destinada a producir efectos jurídicos de forma inmediata o directa, en relación con aquella que atiende al contenido de la actuación o en relación con la función que se debe cumplir. Desde el punto de vista forma, se distingue la actividad unilateral y la actividad contractual. Por su parte, desde el punto de vista sustancial se distingue entre actividad de policía u ordenación, actividad de servicio público y actividad de fomento. Véase SANTAMARIA 2016, 285-288; PAREJO 2020, 545-548. En Chile, CAMACHO 2010.

7 Entre otros, Dictámenes Nos 12868, de 1981; 25310, de 2000; 27132, de 2001; 31636, de 2001; 34252, de 2001; 35624, de 2001 y 12272, de 2002. 
la doctrina ${ }^{8}$, lo que se ha visto reforzado con la LBPA?. De esta forma, se entiende que son decisiones formales ${ }^{10}$ que emiten los órganos de la Administración del Estado ${ }^{11}$ en las cuales se contienen declaraciones de voluntad ${ }^{12}$, realizadas en el ejercicio de una potestad pública ${ }^{13}$.

Por su parte, desde una perspectiva substancial, el permiso de construcción constituye un acto de autorización que tiene por objeto remover una prohibición general para construir, sujeto a un control previo de la autoridad

\footnotetext{
8 VALENZUeLA 1991-1992, 97.

9 RAJEVIC 2004, 183-208. Por tal razón, la Contraloría ha señalado que aquello es concordante con lo dispuesto en dicho cuerpo legal en su artículo $3^{\circ}$. Dictamen $N^{\circ} 48334$, de 2008.

10 El permiso de construcción adopta la forma de resolución, ya sea que la emita la DOM o las SEREMI. Debemos recordar que el artículo $3^{\circ}$ de la LBPA dispone que, a diferencia de los decretos supremos que emite el Presidente de la República o los Ministros "Por orden del Presidente", las resoluciones son los actos de análoga naturaleza que dictan las autoridades administrativas dotadas de poder de decisión.
}

11 Por regla general, los permisos de construcción son emitidos por los Directores de Obras Municipales (DOM), como órgano que forma parte de la Municipalidad. Por excepción, y en el caso que la Municipalidad no cuente con Director de Obras Municipales, los permisos serán otorgados por la Secretaría Regional correspondiente del Ministerio de la Vivienda y Urbanismo. Véase Artículo 11 de la Ley General de Urbanismo y Construcciones (LGUC). Debemos tener presente que las municipalidades correspondientes a comunas con una población inferior a cien mil habitantes no tienen la obligación de contar con una unidad de obras municipales (Artículos 15 y 16 de la Ley $N^{\circ} 18.695$, Orgánica Constitucional de Municipalidades). Por lo tanto, en el caso en que esta exista pero que no cuente con un titular en ejercicio, corresponde aplicar las reglas de subrogación prevista en el Estatuto Municipal (Artículos 76 a 81 de la Ley $N^{\circ} 18.883$, que aprueba el Estatuto Administrativo para funcionarios municipales. En el mismo sentido se pueden consultar los Dictámenes Nos 35.046, de 2001; 7.308, de 2002; 80.449, de 2012; y 21.213, de 2015). Así, solo una vez que han operado sin resultado las normas de subrogación, las Secretarías Regionales Ministeriales de Vivienda y Urbanismo (SEREMI) pueden actuar en virtud de lo dispuesto en el artículo 11 de la Ley General de Urbanismo y Construcciones, contenido en el DFL N 458, de 1976, del Ministerio de Vivienda y Urbanismo (LGUC), otorgando los permisos correspondientes.

12 En este caso la declaración consiste en conceder el permiso o la autorización requerida. Para este efecto se establecen dos condiciones: a) Que, de acuerdo con los antecedentes acompañados, los proyectos cumplen con las normas urbanísticas, y b) El pago de los derechos municipales que procedan. Véase Artículo 116 inciso $3^{\circ}$, de la LGUC.

${ }^{13}$ De acuerdo con la Ley Orgánica Constitucional de Municipalidades (LOCM), cuyo texto refundido, coordinado y sistematizado fue fijado por el DFL $N^{\circ} 1$, de 2006, del Ministerio del Interior, dentro de las funciones privativas de las municipalidades se comprende la aplicación de las disposiciones sobre construcción y urbanización, en la forma que determinen las leyes, sujetándose a las normas técnicas de carácter general que dicte el ministerio respectivo (Artículo 3 letra e) LOCM ). En tal sentido, se encomienda a la unidad encargada de obras municipales velar por el cumplimiento de las disposiciones de la LGUC, del plan regulador comunal y de las ordenanzas correspondientes, gozando para tal efecto de las atribuciones específicas de aprobar las subdivisiones de predios urbanos y urbano-rurales; dar aprobación a los proyectos de obras de urbanización y de construcción; otorgar los permisos de edificación de las obras señaladas; fiscalizar la ejecución de dichas obras hasta el momento de su recepción, y recibir las obras y autorizar su uso (Artículo 24 letra a) LOCM). Esto además está en concordancia con lo dispuesto en la LGUC, que establece que la construcción, reconstrucción, reparación, alteración, ampliación y demolición de edificios y obras de urbanización de cualquier naturaleza, sean urbanas o rurales, requerirán permiso de la Dirección de Obras Municipales (Artículo 116 LGUC). 
administrativa ${ }^{14}$. Desde una visión tradicional, la autorización administrativa supone varios elementos concurrentes: a) la existencia de un derecho preexistente y configurado por el ordenamiento jurídico; b) la prohibición y condicionamiento para el ejercicio de dicho derecho a la voluntad de un órgano de la Administración a través de un acto administrativo formal; c) la ilicitud y/o ilegalidad en el ejercicio del derecho por parte de su titular mientras no cuente con dicho pronunciamiento por parte de la Administración; d) la comprobación previa por parte de la Administración del cumplimiento de las condiciones legales que permitan el ejercicio del derecho, y e) la remoción de la prohibición en el caso que se cumplan con dichas condiciones, permitiendo y haciendo lícito el ejercicio del derecho ${ }^{15}$.

Ahora bien, la introducción de esta técnica de intervención tiene lugar respecto de aquellas actividades en las cuales existe un interés público comprometido y que exige adoptar por parte de los órganos estatales los mayores resguardos para permitirlas, aunque sujetas a una mayor supervigilancia y control durante su desarrollo. Si bien la doctrina ha discutido los presupuestos de la autorización administrativa, ya que no siempre es posible encontrar un derecho subjetivo configurado de forma precisa, y muchas veces lo que existe es el ejercicio de una libertad económica o empresarial ${ }^{16}$, en materia urbanística ocurre exactamente lo contrario. En efecto, los márgenes de discrecionalidad con que cuenta la autoridad urbanística en el marco de la planificación urbana caen abruptamente cuando se trata de la autorización de actuaciones concretas en el territorio. En este caso, los instrumentos de planificación territorial han materializado la potestad de planificación de forma normativa, de manera que los propietarios pueden determinar con precisión cuáles son sus facultades para edificar y usar el espacio. Sin embargo, las posibilidades de patrimonializar efectivamente dichas facultades quedan sujetas a un control previo que tiene por finalidad comprobar que el proyecto o actividad a realizar se conforma con dichas previsiones normativas. La planificación urbana pre configura el derecho y la autorización administrativa, bajo la forma de un permiso de edificación, habilita para su ejercicio.

\footnotetext{
14 Entre otros, García de Enterría y Parejo 1981, 648 y Parada 2013, 418. El permiso de construcción o licencia urbanística no se ha asimilado a un acto concesional, considerando que en este caso no se crea un derecho ex novo, sino que se permite ejercer el derecho de propiedad cuyo contenido material está preconfigurado por el ordenamiento, particularmente por los instrumentos de planificación territorial. Véase Garrido FALLA 2002, 175-179; GARRIDO FAlLA 1959, 25-20; SANTAMARÍa 2016, 305-311. En todo caso, el concepto tradicional de autorización formulado por Otto Mayer y Ranelleti en muchos casos no logra establecer una clara distinción con las concesiones. Véase García de Enterría y FernÁndez 2008b, 135-137, pero existen algunos elementos básicos que, en el caso del permiso, permiten sostener su carácter de autorización, como es la existencia de una prohibición general previa que opera sobre la actividad de los particulares, propio de la vieja actividad de policía, la cual dio origen en el siglo XIX a la policía urbana. Ver CORDERO 2015, 128-130. A diferencia de lo que sucede con la concesión, que supone una publicatio o reserva formal del sector a los entes públicos. Vergara 1992, 283.

15 Garrido Falla 2002, 175-179; Garrido Falla 1959, 25-20; Santamaría 2016, 305-311.

16 Santamaría 2016, 307.
} 
En tal sentido, algunos autores ponen el acento en esta perspectiva para definir el permiso de edificación como "un acto de autorización que remueve los obstáculos que se oponen al libre ejercicio de un derecho del que ya es titular un propietario, previa comprobación de que dicho ejercicio se ajusta al ordenamiento y a las prescripciones establecidas en los Planes"17.

En el caso particular de nuestro país, la doctrina ha dado algunas definiciones bastante descriptivas y muy apegadas al texto legal, sosteniendo que el permiso de construcción es:

"el acto jurídico municipal, que consiste en una autorización administrativa previa y obligatoria, para quien pretende construir, reconstruir, reparar, alterar, ampliar o demoler edificios y obras de urbanización de cualquier naturaleza, sean urbanas o rurales, la cual es otorgada por el Director de Obras Municipales competente, luego de haber certificado que el proyecto respectivo cumple con las normas del Plano Regulador, la Ley General de Urbanismo y Construcción y la Ordenanza General respectiva, teniendo en cuenta el terreno sobre el cual se va a ejecutar la construcción, respecto del terreno en que se va a ejecutar y sin perjuicio de las excepciones legales"18.

Aunque posteriormente se ha asumido una posición dogmática tradicional de comprenderla como:

"un acto administrativo mediante el cual el D.O.M. (sic) competente autoriza al propietario de un terreno para urbanizarlo y/o construirlo por estar su proyecto ajustado a la normativa urbanística aplicable a este tipo de obras. Este reconocimiento da forma a un derecho preexistente, incorporándose al patrimonio del peticionario, como derecho adquirido"19.

En una línea similar, vamos a señalar que el permiso de construcción es un acto administrativo de autorización otorgado por la autoridad competente y que tiene por objeto comprobar de forma previa que un proyecto de edificación o uso del suelo se conforma con la normativa urbanística, incorporando en el patrimonio del titular dichas facultades, sujeto a la condición de ejercerlas dentro de un cierto plazo.

\section{El Marco regulatorio del permiso de construcción}

Como hemos señalado, la jurisprudencia y la doctrina han reconocido que el permiso de construcción es un acto administrativo, lo que tiene como con-

\footnotetext{
17 Parada 2013, 418.

18 VALENZUELA 1989, 7. En una publicación posterior la define en términos más amplios como un acto municipal consistente en una autorización previa y obligatoria para todo "aquel que pretende erigir una obra, y que se otorga una vez verificado que el proyecto cumple con las normas del Plano Regulador, la Ley General de Urbanismo y Construcciones, la Ordenanza General respectiva, teniendo en cuenta el terreno sobre el cual se va a ejecutar la construcción", en VALENZUELA 1991-1992, 97-124.

19 Figueroa y Figueroa 2016, 224.
} 
secuencia que su marco regulatorio está integrado no solo por las normas urbanísticas, sino también por la legislación administrativa general. Así, es posible reconocer dos niveles normativos que le son aplicables: a) La legislación especial comprendida por la normativa urbanística, esto es, la Ley General de Urbanismo y Construcciones (LGUC) ${ }^{20}$, la Ordenanza General de Urbanismo y Construcciones ${ }^{21}$, los instrumentos de planificación territorial y la interpretación que de los mismos hacen la Dirección de Desarrollo Urbano (DDU) 22 y las SEREMI, y b) La legislación administrativa general, contenida en la Ley $N^{\circ} 18.575$, Orgánica Constitucional de Bases Generales de la Administración, y la Ley $N^{\circ} 19.880$, sobre bases de los procedimientos que rigen los actos de los órganos de la Administración del Estado, que tiene un carácter supletorio ${ }^{23}$.

A su vez, en cuanto acto administrativo resultan también aplicables los conceptos, categorías y elementos que la doctrina y jurisprudencia ha elaborado para su compresión y análisis. Por tal razón, es posible estudiar estos permisos conforme a las clasificaciones que se hacen de los actos administrativos, los elementos que lo componen y los eventuales vicios o irregularidades que afectan su validez ${ }^{24}$. En tal sentido, el permiso de construcción se clasifica dentro de las diversas clases y categorías de actos administrativos que formula la doctrina. Así, podemos considerar los siguientes criterios:

a) Desde la perspectiva sustancial o de su contenido, el permiso contiene una declaración de voluntad de un órgano de la Administración. En efecto, en este caso estamos ante una manifestación de una entidad pública que tiene la capacidad de crear una situación jurídica respecto de los destinatarios, permitiéndole la realización de actos que previamente estaban prohibidos y generando en su patrimonio una facultad que viene a engrosar sus atribuciones sobre el derecho de propiedad sobre el suelo.

b) Atendiendo al margen de apreciación que tiene la autoridad, el permiso de edificación debe ser calificado como un acto administrativo reglado, en la medida que todos sus elementos (autoridad, oportunidad, procedimiento, contenido, fin y forma) están previsto por la ley. Así, la entidad competente tiene que resolver sobre la base de un silogismo que puede resultar

${ }^{20}$ Decreto con Fuerza de Ley $\mathrm{N}^{\circ} 458$, del Ministerio de Vivienda y Urbanismo, de 13 de abril de 1976.

21 Decreto Supremo N 47, del Ministerio de Vivienda y Urbanismo, de 5 de junio de 1992.

22 Sobre esta materia la Contraloría General de la República ha sostenido que si el legislador ha radicado en el Ministerio de Vivienda y Urbanismo, a través de la Dirección de Desarrollo Urbano, la facultad de impartir instrucciones para la aplicación de la Ley General de Urbanismo y Construcciones y de su Ordenanza General, no debe desconocerse que dicha atribución comprende la de interpretar la indicada preceptiva, dado que en derecho, si se faculta para impartir instrucciones destinadas a aplicar sobre determinados preceptos, ello importa previamente determinar el alcance o sentido de ellos (Dictámenes Nos 5.888, de 1999; 39.735, de 2000; y 18.447, de 2004).

${ }^{23}$ Entre otros, Dictamen No 12.305, de 2006.

24 En nuestro país, es el análisis que ha hecho RAJEvic 2004. 
muy simple: si cumple con las condiciones previstas por la ley, se debe otorgar la autorización. En caso contrario, esta debe ser denegada.

c) Es un acto de efectos favorables. Si bien se puede discutir el alcance que tienen los efectos de un acto administrativo, así como lo favorable o desfavorable que este puede ser, no cabe duda de que en este caso el permiso de construcción habilita a su titular para ejercer las facultades urbanísticas conforme a las previsiones del plan, de manera que aumenta su esfera jurídica de actuación. La importancia de esta característica resulta capital al momento de limitar la posibilidad de revocabilidad de los permisos y la restricción de sus efectos en caso de invalidación y buena fe de sus destinatarios, aunque con algunas dudas que se han planteado en la jurisprudencia reciente, como veremos más adelante.

d) Desde el punto de vista procedimental, constituye un acto terminal, que contiene un pronunciamiento de fondo de la Administración respecto de la materia o asunto que ha sido objeto del procedimiento. Esto implica desde el plano formal que siempre debe ser fundado, conteniendo un pronunciamiento respecto todas las cuestiones planteadas por los interesados, debiendo ajustarse a las peticiones formuladas por este ${ }^{25}$. Además, se trata de un acto que puede ser objeto de impugnación tanto por la vía administrativa y judicial, como veremos más adelante.

\section{Algunos problemas del permiso de construcción}

El permiso de construcción ha planteado algunos problemas de interés que han puesto en tensión los conceptos generales del Derecho administrativo nacional y que han debido ser resueltos por la jurisprudencia teniendo presente no solo la solución en el ámbito de la regulación urbana, sino que también las categorías generales de esta disciplina. Para estos efectos, hemos seleccionados aquellos aspectos que consideramos más relevantes y que podemos dividir en los siguientes puntos:

1. Los derechos adquiridos que nacen de un permiso de edificación;

2. La relación del permiso de edificación con otros actos administrativos urbanísticos;

3. La ejecutoriedad del permiso;

4. Los efectos de la nulidad de los permisos de construcción;

5. La invalidación de los permisos de construcción;

6. La caducidad del permiso, y

7. Los medios de impugnación.

25 Artículo 41, inciso tercero de la LBPA. 


\section{Los permisos de construcción y los derechos adquiridos}

Un aspecto de interés en materia urbanística dice relación con la forma en que los cambios en la normativa urbanística permiten mantener las situaciones jurídicas concretas que se han consolidado conforme al régimen anteriormente vigente. Ahora bien, en esta materia la solución tradicional ha sido la de mantener dicho status bajo la figura del "congelamiento" 26 , sin perjuicio de la posibilidad de aplicar derechamente el nuevo régimen, debiendo asumir la Administración el costo de dicha privación, habitualmente a través de la expropiación. Sin embargo, en esta materia se ha planteado una discusión de larga data respecto de la posibilidad de que de un acto administrativo puedan nacer derechos, titularidades o situaciones jurídicas a favor de su destinario y que, por tanto, deban ser objeto de resguardo como parte de su estatus personal o patrimonial. En tal sentido, es conocida lo disputa que ha existido desde comienzos del siglo XIX respecto de la posibilidad de que existan derechos subjetivos en el ámbito del Derecho administrativo y que aquellos nazcan de actos de la propia autoridad, no siendo considerados como meras concesiones o medidas de mera tolerancia que no configuran situación jurídica alguna ${ }^{27}$.

En efecto, resulta muy interesante la discusión que se presentó en Francia y Alemania sobre este tema. En general, los autores no desconocían la existencia de derechos de contenido patrimonial que surgen a partir de actos administrativos, sino la posibilidad de que pudieran configurar derechos reales sobre bienes públicos ${ }^{28}$, colocando en posiciones antagónicas a autores tan importantes como Maurice HAUORIOU ${ }^{29}$, Ernst FORSTHOFF ${ }^{30}$ y Guido ZANOBINI ${ }^{31}$, que admiten dicha posibilidad, frente a juristas del peso como León DuguiT ${ }^{32}$, Henry BerTHELmY ${ }^{33}$ y Rogerd BONNARD ${ }^{34}$, que sostenían la posición contraria. Por lo demás, en nuestro entorno se asentó una suerte de principio o adagio en los términos siguiente: "en Derecho público no hay derechos adquiridos", formulación hecha para explicar el régimen estatutario de los funcionarios públi-

\footnotetext{
26 En este sentido, el artículo 62 LGUC dispone que "los terrenos cuyo uso no se conformare con el Plan Regulador se entenderán congelados, en el sentido de que no podrá aumentarse el volumen de construcción en ellos existentes, rehacer las instalaciones, ni otorgarse patente a nuevo propietario o arrendatarios".

27 Sobre la discusión en Chile se puede ver Soto KLOSS (1984) y (1995), 221 y ss., y DÍAZ DE VALDÉS y ENTEICHE 2015, 235-266. En todo caso, es generalmente aceptada la producción de derechos o situaciones jurídicas a partir de actos administrativos y los límites que se imponen a la autoridad administrativa. Véase Forsthoff (1954), 173, 217-219; ZANOBINI 1958, T. I, 261-264, $327-328$ y García de Enterría y Fernández 2008a, 578-580.

28 Sobre la materia se ha utilizado la expresión de "derechos reales administrativos", véase GoNZÁLEZ (1989); VERGARA (1992), 315-328, y DESDENTADO (1999).

29 HAURIOU 1908, 65.

30 FORSTHOFF 1954, 305-307.

31 ZANOBINI 1958, T. IV, 36-37.

32 Duguit 1923, 357.

33 Berthelmy 1913, 425.

34 BonNARD 1943, 732.
} 
cos, pero que luego fue proyectada con carácter general a todo el ámbito del Derecho administrativo ${ }^{35}$. Sin embargo, se trata de una posición que ha sido ampliamente superada en todo ámbito. Bien se dirá que:

"[...] contrariamente a lo que con extrema ligereza intelectual se enseñaba hace años en las cátedras de Derecho Administrativo, los actos administrativos, como actos jurídicos que son, producen efectos jurídicos; al producir efectos, éstos ingresan a la esfera jurídica de los sujetos a quienes afecta (sea en beneficio, sea en gravamen o carga) y, por consiguiente, ingresan a su patrimonio y poseen, por ende, un derecho de propiedad sobre ellos" 36 .

En tal sentido, los derechos que nacen de un acto administrativo son de naturaleza incorporal, los cuales se incorporan al patrimonio de su destinatario, cualquiera sea el derecho, interés, situación o posición jurídica que se reconozca. Por lo demás, esta situación se corresponde con la tendencia de proteger la propiedad en su más amplia dimensión, esto es, en todos los casos en que exista un interés de contenido pecuniario, tesis que fue sostenida y desarrollada originalmente por la doctrina alemana en el período entre guerras ${ }^{37}$, para la cual no hay diferencia entre la expropiación y una simple limitación al ejercicio del derecho de propiedad, ya que toda intromisión por parte del poder estatal en la esfera patrimonial privada quedaba cubierta por la correspondiente indemnización, prevista para las expropiaciones ${ }^{38}$.

En el caso de Chile, la extensión de la garantía de la propiedad a la protección de la integridad patrimonial está estrechamente marcada por el

35 Véase Soto KLoss 1984, 13 y ss. También del mismo autor 1995, 211 y ss.

36 Sото KLosS 1991, 192.

37 El origen de esta doctrina se encuentra en el pensamiento del jurista alemán Martín Wolff (1872-1953) en su disertación Reichsverfassung und Eigentum en Festgabe für Wilhelm Kahl, 1923. El objeto de su trabajo fue ampliar el contenido y los alcances de la garantía del derecho propiedad, haciendo retroceder o poniendo freno a las tendencias socializadoras que aparecían con toda claridad en el artículo 153 de la Constitución de Weimar de 1919. Así se llega a postular que la garantía constitucional de la propiedad comprende no solo el derecho de propiedad definido en el parágrafo 903 del BGB sino "cualquier derecho patrimonial (crédito, acción derecho real, derecho de autor)". Idem. 3. Martín Wolff fue seguido en esta tesis por la mayoría de los especialistas (Triepel, 1924; Anschuetz 1929, 607; Giese 1921, 392; Poetsch-Heffter, 1928, 482, aunque en un sentido contrario se pronunció HOFACKER, así como por la jurisprudencia del Reichsgericht (RGZ 103, S. 200 (201 f.); 109, S. 310 (319); 111, S. 123 (130); 111, S. 320 (328); 121, S. 166 (168); 128, S. 165 (171); 129, S. 146 (148); 136, S. 113 (123); 139, S. 177 (188). Las referencias han sido tomadas de los comentarios de PAPIER 2009, 11-17, que fue eliminando paulatinamente las características tradicionales de la institución de la expropiación, manteniendo esta interpretación incluso tras la llegada al poder del nacionalsocialismo. En palabras de ScHMITT, Carl, en Juristiche Wochenschrift, 1929, 459 y ss. se produjo una "disolución de la noción de expropiación". Según Triepel esta garantía sería no solo un límite para la Administración, sino también para el Legislador.

38 Vid. Brahm 1992, 411-414. Con posterioridad, no solo se ha confirmado la vigencia de esta interpretación a la luz de la Ley Fundamental de Bon por parte del Tribunal Constitucional Alemán en una de sus primeras sentencias y por la doctrina, sino que se ha reforzado la protección, al punto que se ha extendido la garantía constitucional a las posiciones jurídico-públicas con contenido patrimonial. 
objeto sobre el cual recae dicho resguardo, abarcando por la vía jurisprudencial no solo las cosas o bienes corporales, sino también aquellas cosas o bienes incorporales. En efecto, esto surge en un caso planteado ante la Corte Suprema en el año 196839, doctrina que pasó a ser jurisprudencia uniforme de la Corte Suprema ${ }^{40}$ y se ha consolidado en la dogmática jurídica chilena, casi sin discusión ${ }^{41}$. Así las cosas, se experimenta una extensión del derecho de propiedad, ya que la expresión "el derecho de propiedad en sus diversas especies" unido a una interpretación sistemática con el Código Civil, da a entender que hay un derecho de propiedad sobre las cosas incorporales, las que consisten en derechos reales y personales. Dicho, en otros términos, se puede ser propietario no solo de cosas corporales, cualquiera sea su naturaleza física, sino que también de derechos, como son el usufructo, las servidumbres o los créditos. De esta forma, si se violenta o se priva a una persona de su derecho a cobrar un crédito o se le imponen cargas que hacen imposible su cobro, se está afectando su derecho de propiedad sobre el crédito que está garantizado constitucionalmente ${ }^{42}$. Sobre tales premisas, no es difícil sostener que del permiso de edificación surgen situaciones o posiciones jurídicas de contenido patrimonial que están amparadas por esta garantía constitucional.

${ }_{39}$ El caso Troncoso G.H., Julia se origina a raíz de la interposición de un recurso de inaplicabilidad a un contrato de arrendamiento del artículo 2 transitorio del DFL $N^{\circ} 9$ de 1968, el que disponía la vigencia inmediata de su artículo 11, por el cual el plazo mínimo de todo contrato de arrendamiento sobre predios rústicos sería de 10 años. En caso de celebrarse por un menor plazo, se entendía pactado por el lapso de 10 años. El caso que suscita el pronunciamiento del tribunal fue el conflicto planteado entre arrendador y arrendatario de un predio rústico, contrato celebrado en 1965 y pactado por un período de 3 años, al término del cual el arrendatario se negó a la restitución asilándose en la norma ya comentada. Interpuesto el recurso de inaplicabilidad, la Corte Suprema lo acoge, señalando que el arrendador había adquirido un derecho personal a la restitución del predio al cabo de los tres años convenidos, sobre el cual como cosa incorporal tenía propiedad, sin importar la circunstancia de que la ocasión de hacerlo valer se presentara en una época posterior, en que una nueva ley se encuentra vigente. Tal propiedad estaba amparada por el artículo 10 № 10 de la Constitución de 1925, por lo que, siendo inconstitucional en este caso, resultaba inaplicable el artículo 2 transitorio del DFL $N^{\circ} 9$ de 1968. Cfr. Sentencia de la Corte Suprema de 24 de diciembre de 1968., en RDJ, T. 65, 1968, $2^{a}$ parte, sec. 1, 392 y ss. Existe un caso anterior (Sentencia de la Corte Suprema de 21 de diciembre de 1949. Aida Blanco, inaplicablidad. en RDJ, T. 47, 1950, sec. 1, 30 y ss.), pero que no tuvo la relevancia e influencia del caso anterior, sin perjuicio de que este tema es tocado muy superficialmente, como lo destaca GuZMÁn 1995, 237, nota 251.

40 Corte Suprema Rol No 10.096; Rol No 10.055; y Rol No 11.212.

${ }^{41}$ Con una abundante cita jurisprudencial vid. FUENTES 1997, 38 y ss.

42 En este sentido, véase Tribunal Constitucional Roles Nos 505-2006 y 506-2006. En tal sentido, esta Magistratura ha reconocido la garantía del derecho de propiedad no solo sobre bienes corporales, sino también respecto de bienes incorporales, como sucede con los derechos personales que emanan de un contrato (Tribunal Constitucional. Roles Nos 505-2006, 506-2006, 6982006, y 1309-2010). En todo caso, esta tendencia se ve reforzada por la introducción del recurso de protección y el ejercicio habitual que se hizo de esta acción respecto de derechos que no reúnen las características tradicionales del dominio, fenómeno que fue conocido en la década de los noventa del siglo pasado como la "propietarización de los derechos". Véase Vergara 1991 y GuZMÁN 1995. 
Ahora bien, en este caso existen tres cuestiones que resultan capitales en relación con los derechos y la situación jurídica en la cual se encuentran sus destinatarios, a saber:

a) Cuáles son los derechos que se adquieren en virtud del permiso;

b) En qué momento se produce dicho efecto, y

c) Las condiciones se deben cumplir en relación con la legalidad del acto que los otorga.

En relación con los derechos que nacen de un permiso, debemos tener presente que los instrumentos de planificación territorial determinan el contenido material del derecho de propiedad sobre el suelo, a través de normas destinadas a una ordenación racional del mismo mediante la determinación de reglas de uso y edificación ${ }^{43}$. A su vez, el permiso es un instrumento de control preventivo destinado a establecer si se han cumplido con las cargas urbanísticas previstas en el plan y si el proyecto es concordante con el mismo. En este caso, el otorgamiento del permiso permite el ejercicio del ius aedificandi que viene pre configurado en el marco de las facultades y deberes inherentes del derecho de propiedad, conforme a la legislación urbanística y, particularmente, de los instrumentos de planificación territorial ${ }^{44}$. Así, visto desde un punto de vista objetivo el permiso tiene por finalidad determinar la legalidad en la actuación que puede realizar el propietario y, desde la perspectiva subjetiva, se traduce en que se incorpora en su patrimonio bajo la forma de una facultad o derecho el uso y la edificabilidad prevista en la norma. De esta manera, lo que es un marco objetivo de regulación, se singulariza en la esfera jurídica de una persona respecto de las facultades urbanística que se le reconocen, de las cuales solo puede ser privado en virtud de una expropiación y previo pago de la respectiva indemnización. Así, sobre el suelo se proyecta una realidad virtual que tiene un contenido patrimonial y que permite su materialización a través de las obras de urbanización y construcción, sujeto en todo caso a los términos y plazos previstos por el ordenamiento, todo lo cual es sin perjuicio de otros permisos o autorizaciones que se deban obtener conforme a la legislación sectorial.

\footnotetext{
43 Cordero 2015, 131-132.

44 En nuestro ordenamiento, así como en el Derecho comparado, se ha discutido si el ius aedificandi preexiste a los instrumentos de planificación o, si por el contrario, es el instrumento de planeamiento el que lo atribuye y da existencia, de modo que el aprovechamiento nace en el tiempo, modo o cuantía que el planeamiento y la legislación urbanística, pudiendo incluso no corresponder nunca al propietario. Sin embargo, ha predominado la idea de que la función social de la propiedad en el derecho a edificar se traduce en una plena dependencia del ius aedificandi al planeamiento, de tal manera que el propietario no tiene derecho alguno a edificar, sino una mera "expectativa" dependiente del cumplimiento de los deberes. PAREJO 1988, 438-439; Cordero 2015, 128, CORDERO 2008, 103.
} 
El segundo punto dice relación con el momento en que se produce esta "patrimonialización" 45 . En este caso, debemos estar a la regla general respecto de la ejecutoriedad de los actos administrativos, sin perjuicio de lo que más adelante se dirá sobre su impugnación. Por lo tanto, los efectos del permiso de edificación y la incorporación en el patrimonio de su titular del uso y la edificabilidad tendrá lugar mediante el acto de notificación ${ }^{46}$. Sin embargo, también se ha planteado alguna discusión con otros actos administrativos urbanísticos previos, como son el certificado de informaciones previas (CIP) y los anteproyectos, en relación con el carácter vinculante que tendrían respecto del permiso de construcción y la posibilidad de dar lugar a derechos adquiridos aun antes de su notificación, como lo veremos en el siguiente apartado.

Por último, el tercer aspecto dice relación con las condiciones que se deben cumplir para que se produzca esta adquisición considerando la legalidad del permiso. En efecto, como lo analizaremos más adelante, no cabe discusión que de un acto administrativo que cumple con todas las condiciones de legalidad nazcan derechos que se incorporan en el patrimonio de sus destinatarios y que, por tanto, están amparados por la garantía constitucional de la integridad patrimonial (artículo $19 \mathrm{~N}^{\circ} 24$ de la Constitución). El problema se presenta respecto de los actos administrativos ilegales y los efectos que producen respecto de los titulares de proyectos que se encuentran de buena fe, cuestión que analizaremos a propósito de la nulidad e invalidación de los permisos de construcción.

2. La relación del permiso de edificación con otros actos administrativos urbanísticos

En materia urbanística nos encontramos con un amplio número de actos administrativos, todos los cuales están estrechamente vinculados al permiso de construcción. Así sucede con el CIP, los anteproyectos y la recepción de las obras. Si bien no se trata de actos que necesariamente deban emitirse respecto de todo proyecto, es habitual que se soliciten para tener certeza de las condiciones urbanística del suelo, conservar la normativa vigente, ejecutar las obras y permitir su uso y destino. Ahora bien, desde el punto de vista jurídico la discusión se ha planteado respecto de los efectos que producen cada uno de estos actos y la forma en que condicionan al permiso de edificación. Este también es un tema que se vincula con la legalidad de estos actos administrativos y los derechos adquiridos a que pueden dar lugar, como veremos a continuación.

\footnotetext{
45 Esta expresión ha sido acuñada por PAREJO ALFONSO y refleja de la mejor forma los aspectos positivos o de beneficios que produce la licencia urbanística o el permiso respecto del propietario. Véase PAREJo 2017, 11-12, entro otros trabajos.

${ }^{46}$ Artículos 3 inciso final, 45 y 51 de la LBPA. En la misma línea, la Corte Suprema ha señalado que los actos administrativos producen sus efectos de manera inmediata, sus consecuencias jurídicas y materiales se radican en el patrimonio del administrado desde el momento mismo de su notificación. Véase Corte Suprema. Rol N 1.079-2014, considerando $11^{\circ}$.
} 

resado:

En primer término, la LGUC establece que la DOM, a petición del inte-

"[...] emitirá un certificado de informaciones previas que contenga las condiciones aplicables al predio de que se trate, de acuerdo con las normas urbanísticas derivadas del instrumento de planificación territorial respectivo. El certificado mantendrá su validez mientras no se modifiquen las normas urbanísticas, legales o reglamentarias pertinentes" ${ }^{47}$.

Este certificado constituye un acto administrativo de constancia o conocimiento, tal como lo dispone el artículo $3^{\circ}$ de la LBPA. Por lo tanto, no contiene decisión o pronunciamiento alguno por parte de la autoridad que implique alguna declaración de voluntad que pueda afectar la esfera jurídica de su destinatario, ya sea de forma favorable o desfavorable. En este caso, la DOM se limita a dar constancia del régimen urbanismo aplicable a un determinado ámbito territorial conforme a la normativa vigente.

A su vez, dicho acto debe ser acompañado a la solicitud de un permiso de edificación o aprobación de anteproyecto, de acuerdo con lo establecido por la OGUC, ya que entrega los elementos de juicio que permiten a la DOM otorgar o denegar el otorgamiento del permiso o la aprobación del anteproyecto.

Sin embargo, nuestra jurisprudencia fue un poco más lejos y llegó a sostener que un CIP podría ser vinculante para la autoridad respecto de la emisión de estos actos posteriores (aprobación de anteproyectos y otorgamiento de permisos), aun cuando contuviera errores. De esta forma, se sostuvo que los CIP emitidos por autoridad competente eran actos administrativos perfectos que producen pleno efecto para sus destinatarios, cuyos derechos, derivados legítimamente de tales certificados, no pueden desconocerse posteriormente. Así, desde la fecha en que dichos certificados fueron otorgados por la DOM, debía ajustarse a ellos en sus resoluciones, en consideración a la validez legal que han adquirido en su carácter de actos administrativos perfectos ${ }^{48}$.

No obstante, este criterio sufrió un cambió a partir del año 2000, cuando la Corte Suprema sostuvo que no nacían derechos adquiridos a partir de un CIP que contenga un error de la autoridad municipal, por lo que esta puede enmendarlo negándose a otorgar el permiso o autorizar el anteproyecto respectivo:

"En este aspecto cabe señalar que el certificado de informaciones previas debe conformarse estrictamente a las normas urbanísticas vigentes en las materias antes señaladas, pues su validez deriva de tal circunstancia. De modo que solo si se cumple tal requisito se producirá el efecto de mantener su vigencia mientras no se modifiquen las normas urbanís-

\footnotetext{
47 Artículo 116 inciso $7^{\circ}$ de la LGUC.

${ }_{48}$ Corte de Apelaciones de Santiago, Rol No 1.190-99. En igual sentido se ha pronunciado la Corte Suprema. Rol No 4.073-1998 y la Corte de Apelaciones de Antofagasta, Rol No 12.447, confirmada por la Corte Suprema. Rol N³.022-99.
} 
ticas, legales o reglamentarias pertinentes. Así, si un certificado se emite contrariando las normas urbanísticas, este carecerá de todo valor, estando la autoridad administrativa obligada a dejarlo sin efecto"49.

El mismo criterio fue sostenido posteriormente por la Contraloría General de la República, que ha señalado que:

"[...] los CIP no fijan las condiciones jurídicas aplicables a los inmuebles ni generan derechos adquiridos para sus propietarios, sino que constituyen documentos a través de los cuales las Direcciones de Obras Municipales dan cuenta, entre otras circunstancias, de las normas urbanísticas que les son aplicables a aquellos, de acuerdo con lo consignado en los planes reguladores, según la zona o subzona en que se encuentren situados" ${ }^{50}$.

De esta forma, se produce una desvinculación del CIP respecto de los anteproyectos y del permiso de edificación en relación con las condiciones urbanísticas que determinan su contenido. En todo caso, no es posible soslayar que un error en un dicho acto puede ocasionar un serio perjuicio de terceros, considerando que el valor del suelo depende del destino y edificabilidad que pueda tener asignado. Así, una equivocación en la normativa aplicable no es una cuestión menor, más aún cuando está contenida en un acto formal que emana de la autoridad competente. En tal sentido, resulta interesante que la jurisprudencia haya reconocido que este hecho puede constituir una falta de servicio y, si ha producido algún daño o perjuicio a un particular, aquello da lugar a responsabilidad patrimonial de la municipalidad ${ }^{51}$.

En segundo término, nos encontramos con los anteproyectos, que son actos administrativos que permiten al solicitante mantener vigente las condiciones previstas en la normativa urbanística, con el fin de precaver cualquier modificación o cambio que estas puedan experimentar ${ }^{52}$. En efecto, considerando la flexibilidad que tiene la regulación urbanística a través de los instrumentos de planificación territorial, es posible que se experimenten cambios en la misma que impidan tener certeza respecto de la ejecución de

\footnotetext{
49 Corte Suprema Rol No 23.766-2014. En el mismo sentido, Corte Suprema Roles No 40-2000 y 3.104-2002 y Contraloría dictámenes Nos 49.531, de 2008, 77.490, de 2011 y 7.992, de 2017.

50 Dictamen № 23.573, de 2015. En el mismo sentido, dictámenes №s 30.891 y 45.377, de 2012.

51 Corte Suprema Rol No 5080-2011, en la cual señala que "de acuerdo a los hechos asentados es manifiesto el incumplimiento de la norma legal en el quehacer municipal, que motiva la responsabilidad del Municipio demandado por falta de servicio". En un sentido similar, Corte Suprema Rol No 9433-2011, en especial el considerando $8^{\circ}$.

52 Siguiendo lo dispuesto en Artículo 116 inciso $8^{\circ}$ LGUC, la OGUC define los anteproyectos como la "presentación previa de un proyecto de loteo, de edificación o de urbanización, en el cual se contemplan los aspectos esenciales relacionados con la aplicación de las normas urbanísticas y que una vez aprobado mantiene vigentes todas las condiciones urbanísticas del Instrumento de Planificación respectivo y de la Ordenanza General de Urbanismo y Construcciones consideradas en aquél y con las que éste se hubiera aprobado, para los efectos de la obtención del permiso correspondiente, durante el plazo que señala esta Ordenanza" (Artículo 1.1.2. de la OGUC).
} 
un proyecto inmobiliario, especialmente en lo que dice relación con la inversión y las condiciones previstas en los actos y contratos necesarios para su materialización. Por tal razón, el anteproyecto permite al propietario poder fijar las normas y condiciones aplicables durante un tiempo, siempre que sea aprobado previamente por la $\mathrm{DOM}^{53}$.

Por su parte, la jurisprudencia también había reconocido que los anteproyectos tenían la capacidad de generar derechos adquiridos a favor del solicitante en relación con las condiciones urbanísticas vigentes, incluso en los casos que se contengan errores que determinen su ilegalidad sobre la base de la buena fe y la confianza legítima ${ }^{54}$. Así, el permiso de construcción debía otorgarse sobre la base del anteproyecto aprobado, a pesar de dichos errores. Sin embargo, con posterioridad se limitó el alcance de dicha interpretación, sosteniendo que los anteproyectos solo tienen por finalidad mantener las condiciones urbanísticas frente a una eventual modificación del instrumento de planificación. Por lo tanto, en el caso que aquello no se produzca, se debe entender que aquello no daría lugar a derechos adquiridos ${ }^{55}$. Como consecuencia de lo anterior, tampoco se plantean limitaciones respecto a su invalidación, desvinculando sus efectos respecto del permiso de construcción, el cual se debe otorgar conforme a las normas urbanísticas vigentes ${ }^{56}$. A su vez, la Corte Suprema ha declarado la nulidad de los anteproyectos, sin considerar la buena o mala fe que haya tenido su titular ${ }^{57}$.

Por último, nos encontramos con la recepción de obras, que también ha sido reconocido como un acto administrativo de constancia o conocimiento ${ }^{58}$,

\footnotetext{
53 Para este efecto se establece un procedimiento administrativo previsto en la OGUC para anteproyectos de loteos (Artículo 3.1.4. de la OGUC) y edificación (Artículo 5.1.5. de la OGUC). A su vez, en relación con los plazos, también se establece un término de 30 días para que la DOM emita su pronunciamiento (Artículo 1.4.10 de la OGUC). Por regla general, el plazo de vigencia de los anteproyectos será de 180 días, salvo en determinados casos en que el plazo se extiende a 1 año si se trata de anteproyectos de loteo cuya superficie sea superior a 5 hectáreas; de anteproyectos de edificación cuya superficie edificada sea superior a $10.000 \mathrm{~m} 2$, o de anteproyectos que requieran, para obtener el permiso de edificación o urbanización, el pronunciamiento de otra repartición pública (Artículo 1.4.11 de la OGUC). A su vez, la Contraloría ha señalado que este plazo se debe contar a partir de la notificación que se hace de la aprobación dada por la DOM, conforme a las normas de la LBPA (Dictámenes $N^{\circ} 29.192$, de 2006 y 32.357, de 2006).

54 Sentencia de la Corte Apelaciones de Antofagasta, Rol N 12.447-99, confirmada por la Corte Suprema. Rol No3.022-99.

55 En tal sentido, Contraloría dictámenes ha señalado que: "los anteproyectos válidamente aprobados, para los efectos de la obtención del permiso correspondiente, mantienen vigentes las condiciones urbanísticas del instrumento de planificación territorial y de las normas de la OGUC consideradas en aquél, lo que solo cobra relevancia si existiere un cambio normativo en esas preceptivas que incida en el proyecto, lo que no ha acontecido en la especie" (Dictamen $N^{\circ} 45.217$, de 2016). En el mismo sentido, Dictamen $N^{\circ} 27.918$, de 2018.

56 Dictámenes $N^{\circ} 45.217$, de 2016, y 89.856, de 2016.

57 Corte Suprema Rol No 5980-2017.

58 Figueroa y Figueroa 2016, 299.
} 
que supone un procedimiento administrativo previo, regulado supletoriamente por la LBPA ${ }^{59}$. A este respecto, el artículo 144 de la LGUC dispone que:

"Terminada una obra o parte de la misma que pueda habilitarse independientemente, el propietario y el arquitecto solicitarán su recepción definitiva por la Dirección de Obras Municipales. Sin perjuicio de las recepciones definitivas parciales, habrá, en todo caso, una recepción definitiva del total de las obras".

A su vez, su inciso tercero establece que:

“El Director de Obras deberá revisar únicamente el cumplimiento de las normas urbanísticas aplicables a la obra, conforme al permiso otorgado, y procederá a efectuar la recepción, si fuere procedente".

Como se puede apreciar, en la recepción de obras se debe constatar el cumplimiento de la normativa urbanística durante su ejecución ${ }^{60}$. Por tal razón, es considerado como un acto de certificación o constancia ${ }^{61}$. Sin embargo, también produce importantes efectos jurídicos, pues: a) permite la habitabilidad y destino para el uso previsto para la obra (artículo 145 LGUC); b) en materia de copropiedad, constituye uno de los requisitos para disponer de cada una de las unidades que la componga, ya sea mediante su enajenación o hipoteca, y c) da lugar a la extinción del permiso de construcción, el cual deja de producir sus efectos.

Ahora bien, en este caso la discusión que se ha planteado dice relación con el marco regulatorio que debe tener a la vista el Director de Obras al momento de otorgar la recepción de obras, particularmente cuando se plantean reparos de legalidad respecto del permiso de construcción. En este caso, el problema se traduce en determinar si dicho acto condiciona el otorgamiento de la recepción o la autoridad lo puede soslayar, en la medida que deben respetar las normas urbanísticas. El problema no es menor, si consideramos los aspectos de seguridad jurídica y certeza que se pueden presentar

\footnotetext{
59 En este sentido, la Corte Suprema ha señalado que: "Como todo procedimiento administrativo, se encuentra reglamentado por las normas especiales previstas para él, como asimismo, de forma supletoria, por la Ley No 19.880, por lo que los principios normativos consagrados en este cuerpo legal deben inspirar la interpretación de los preceptos específicos atingentes a la Litis". Corte Suprema Rol No $31.814-2018$, considerando $10^{\circ}$.

$60 \mathrm{Al}$ respecto, también se debe señalar que a la recepción de obras también se le ha reconocido como un mecanismo de comprobación de la legalidad en materia ambiental. En efecto, el artículo 25 bis de la Ley N 19.300, sobre Bases Generales del Medio Ambiente, prevé que las direcciones de obras municipales no podrán otorgar la recepción definitiva si los proyectos o actividades a que se refiere el artículo 10 del mismo cuerpo legal no acreditan haber obtenido una resolución de calificación ambiental favorable.

${ }^{61}$ Así, la Contraloría ha sostenido que "[...] la recepción definitiva constituye una actuación de la Dirección de Obras Municipales cuyo objeto es fiscalizar que lo edificado se ajuste al permiso otorgado y que supone, necesariamente, que exista la debida concordancia entre ambos, siendo pertinente agregar, acorde a la reseñada normativa, que la recepción parcial solo procede en la medida que una parte de la obra pueda habilitarse independientemente (aplica dictamen $N^{\circ}$ 75.392, de 2013, de este origen)", Dictamen Nº 78, de 2014.
} 
en estos casos, especialmente sobre la base de los principios de buena fe y confianza legítima. A su vez, nuevamente se plantea el tema de la vinculación entre los actos administrativos urbanísticos, es decir, si la recepción debe ceñirse estrictamente al permiso, aun cuando aquel pueda ser ilegal. En este sentido, la Corte Suprema en casos similares ya ha emitido algún pronunciamiento en orden a que no resulta posible que, por actos formales posteriores, se pueda revisar la legalidad de actos previos en la medida que no hayan sido objeto de invalidación o declarados nulos en sede judicial62, lo cual nos parece la solución razonable en el caso de la recepción de obras.

\section{La ejecutoriedad del permiso}

El tema de la ejecutoriedad del permiso de edificación está estrechamente vinculado con la forma de computar los plazos de ejecución de este. Ahora bien, la ejecutoriedad o eficacia dice relación con los efectos jurídicos que produce un acto administrativo, ya sea respecto de la Administración autora como de sus destinatarios, creando, modificando o extinguiendo situaciones jurídicas. En tal sentido, el acto existe y es ejecutorio, en la medida que produce en el plano jurídico los efectos que le son propios y, si fuese necesario, será el título que justifique su ejecución material (ejecutividad). Por su parte, esto no se ve afectado por el hecho de que se cuestione la validez o legalidad del acto, ya que como el acto administrativo se presume legal, van a producir los efectos que le son propios mientras que no se declare su ilegalidad, ya sea mediante la invalidación que puede ordenar la autoridad administrativa (artículo 53 de la LBPA) o la nulidad por la autoridad judicial.

Por regla general, los actos administrativos producen eficacia inmediata, es decir, una vez que se han cumplido con todas las etapas del procedimiento administrativo (artículo 51 la LBPA). Sin embargo, en el caso de los actos que producen efectos individuales se requiere de su notificación (artículo 45 y 51 inciso de la LBPA), regla que resulta plenamente aplicable respecto del solicitante y destinatario del permiso de construcción. La discusión se ha planteado respecto de terceros que puedan tener interés en impugnar dicho acto y no han sido notificado del mismo, como sucede con el reclamo de ilegalidad municipal previsto en la Ley $N^{\circ} 18.695$, Orgánica Constitucional de Municipalidades (LOCM), que computa el plazo desde que el acto ha sido publicado o notificado. Sin embargo, hay actos que solo se notifican y no se publican, como sucede con los permisos de construcción, de forma que los terceros no tienen forma de saber en qué momento se han dictado, para poder impugnarlos.

\footnotetext{
62 Así, se ha señalado que el "[...] acto administrativo mediante el que se aprobó la fusión de los predios, anterior a los impugnados, se erige en una garantía de certeza jurídica para el administrado en tanto gozan de "una presunción de legalidad, de imperio y exigibilidad frente a sus destinatarios, desde su entrada en vigencia", como lo dispone el artículo $3^{\circ}$ de la Ley $N^{\circ}$ 19.880". Corte Suprema Rol N4163-2019, considerando 10. En sentido similar, Corte Suprema Rol N²5.784-2016, considerando $20^{\circ}$.
} 
El problema ya se había discutido bajo la anterior Ley Orgánica de Municipalidades contenida en el Decreto Ley No 1.289, de 1976, que establecía una disposición bastante similar al texto actualmente vigente. A este respecto, bien señalaba Pedro Pierry que la ampliación de la legitimación activa para entablar este reclamo planteaba el problema de la forma de contar el plazo de treinta días para interponer el recurso, ya que aquel puede ser ejercido por personas a quienes el acto no va a ser notificado. En tal sentido, expuso dos soluciones: a) contar el plazo desde la fecha de la dictación del acto impugnado, o del día siguiente, siguiendo a la doctrina española, o b) hacer el computo del plazo desde que existe un "conocimiento adquirido" del acto, tal como sostiene la doctrina francesa, aunque precisa que aquella es una solución sustituta de la notificación del interesado y no para los terceros afectados. Así, afirma que:

"Esta solución, aplicada en el siglo pasado por la jurisprudencia francesa, podría quizás aplicarse en el derecho municipal para los terceros agraviados. Debe entenderse notificado cuando razonablemente aparece como cierto que el interesado tomó debido conocimiento del acto administrativo, o no pudo menos de hacerlo dadas las circunstancias, como por ejemplo: el vecino de un inmueble en construcción del permiso para construir otorgado, si habita en la casa contigua. Debe entenderse notificado, para los efectos de la letra b), desde que comenzaron las obras de construcción. El inconveniente grave que tiene la aplicación de esta teoría radica en que su aplicación práctica implica una larga trayectoria jurisprudencial y, por sobre todo, que esto implica dejar algunos recursos indefinidamente abiertos, lo que, sin embargo, se podría solucionar procediendo la Municipalidad a la publicación a sus actos administrativos $[\ldots]^{\prime \prime 63}$.

En todo caso, Pierry termina inclinándose por la primera posición: el plazo debe computarse desde que el acto se ha dictado ${ }^{64}$. Sin embargo, se ha criticado esta última posición y se ha sostenido que respecto de los terceros interesados que no participan del procedimiento administrativo, la carga de impugnar solo es exigible cuando han tomado o pueda inferirse que han tomado conocimiento del acto. Lo interesante de este caso, es que se coloca de cargo del tercero acreditar aquello, pues supone demostrar la vigencia de su pretensión $n^{65}$.

La jurisprudencia en estas materia ha seguido la tesis planteada por Pierry, es decir, que tratándose de actos no publicados ni notificados, el plazo

\footnotetext{
63 PIerRy 2017, 378-382.

64 Idem, 381.

65 Señala este autor que "[..] tratándose de actos que afectan a terceros que no han sido parte en el procedimiento administrativo, el plazo para impugnarlos corre desde que se demuestra que han tomado conocimiento o pueda inferirse que lo han hecho. Esto último podría ser materia de discusión en el respectivo proceso jurisdiccional, y la carga de la prueba es del tercero desde que supone demostrar la vigencia de su pretensión". Véase Hunter AmpUero 2014, 201.
} 
de treinta días debe contarse desde la dictación del acto y no desde la fecha en que se tuvo conocimiento del acto, por cuanto ello resulta contradictorio con la naturaleza misma del reclamo de ilegalidad y la certeza jurídica necesaria, que deriva de la posibilidad de interponer una acción de nulidad con efectos "erga omnes", para lo que es necesario la existencia de plazos ciertos y breves ${ }^{66}$.

Dada esta situación, mediante la Ley $N^{\circ} 19.878$, de 31 de mayo de 2003, se estableció un procedimiento de publicidad para gestiones administrativas relacionadas con la construcción, y que consideró diversas medidas, entre las cuales estaba la posibilidad que el propietario informara al público sobre dicha gestión (instalación de un letrero visible en el lugar de la obra, la comunicación por escrito a los vecinos afectados, la comunicación a través de algún medio masivo y publicación en el diario oficial) ${ }^{67}$. Sin embargo, aquello no dio los resultados esperados y actualmente se trámite una iniciativa legal en la cual se dispone la publicación de los actos administrativos en una plataforma digital que mantendrá el Ministerio de Vivienda y Urbanismo ${ }^{68}$.

Sin perjuicio de lo anterior, en algunos casos nuestro máximo tribunal ha sostenido que algunos permisos de construcción deben ser publicados cuando afecten al interés de toda una comunidad, especialmente en los casos en que están comprometidos aspectos de carácter ambiental, momento a partir del cual se puede contar el plazo para su impugnación ${ }^{69}$.

\section{Los efectos de la nulidad de los permisos de construcción}

El régimen de validez de un permiso de construcción no difiere del régimen general de los actos administrativos. Así, para determinar los vicios o causales de nulidad que le pueden afectar, se hace una relación con los elementos que lo conforman: investidura, competencia, motivos, objeto, fin y forma ${ }^{70}$. Sin embargo, la cuestión que más problemas ha suscitado dice relación con los efectos que produce la declaración de nulidad respecto de los derechos adquiridos por sus destinatarios ${ }^{71}$. Este es uno de los puntos donde se ha

\footnotetext{
66 Corte Suprema Roles Nos 377-2012, 4383-2008 y 4384-2008.

67 Artículo 116 C de la LGUC.

68 Boletín No 11747-03. Este proyecto fue aprobado por el Congreso Nacional, pero fue objeto de un veto por parte del Presidente de la República que se encuentra pendiente de discusión.

69 Corte Suprema Rol No 3.918-2012. Este criterio se analizó en el caso de Inmobiliaria Nueva El Golf, pero se sostuvo que no se daban los supuestos para exigir la publicación. Corte Suprema. Rol N 4.163-2019, considerando $5^{\circ}$.

70 Corte Suprema, Rol N².217-2009, considerando $10^{\circ}$. Así, el permiso debe emanar de una autoridad investigada en su cargo y dentro del ámbito de su competencia (DOM y, excepcionalmente, SEREMI de Vivienda y Urbanismo); debe fundarse en los antecedentes técnicos y las condiciones urbanísticas del terreno (motivos), dando lugar a un pronunciamiento positivo o negativo para el ejercicio de ius aedificandi (objeto), y destinado al fin público específico previsto por la ley; por último, debe cumplir con las formas establecidas en nuestro ordenamiento, tanto respecto del procedimiento administrativo como de la manera en que se debe extender el acto o resolución que contiene dicho pronunciamiento.

71 Véase Días de Valdés y EnTEICHe 2015, 235-266.
} 
producido con mayor intensidad el efecto que hemos descrito como de "ida y retorno" desde el Derecho administrativo general y el Derecho urbanístico, y lo analizaremos considerando no solo la declaración de nulidad judicialmente declarada, sino también la invalidación que, en nuestra opinión, no es sino la nulidad de un acto administrativo declarada por la propia Administración.

En esta línea, durante la segunda mitad del siglo pasado se inicio una importante discusión respecto de la potestad invalidatoria de los órganos administrativos y los derechos adquiridos, la que se fue decantando en la protección de la posición de los particulares frente a los actos ilegales de la Administración creadores de derechos, sobre la base de la buena fe del destinario del acto y la teoría de los actos propios, además de un cuestionamiento a la existencia de esta potestad en nuestro ordenamiento ${ }^{72}$. En su jurisprudencia inicial, la Contraloría sostuvo que no se podía dejar de reconocer la existencia de límites en el ejercicio de la potestad invalidatoria, cuyo desconocimiento atentaría contra principios elementales de seguridad en las relaciones jurídicas. Así, dentro de estas limitaciones, el Ente contralor advertía sobre la conveniencia de proteger a personas que han actuado de buena fe y mantener estabilidad de situaciones jurídicas que revisten carácter de concretas $^{73}$. En una línea similar se pronunció la Corte Suprema a partir de la década de los ochenta, al resolver diversas acciones de protección ${ }^{74}$.

En su desarrollo inicial, este criterio se aplicó respecto del régimen de los funcionarios (nombramientos, ascensos, expiración de funciones, fuero maternal, pensiones, etc), pero con posterioridad esta doctrina se consolidó bajo la noción de confianza legítima, que comienza a aparecer en la jurisprudencia administrativa de comienzos la década del 2000 con particular fuerza en el ámbito del Derecho urbanístico ${ }^{75}$ y se mantendrán con el reconocimiento expreso de la potestad invalidatoria de la Administración en virtud de la LBPA. Así se afirmará que, en razón de los principios de buena fe y de seguridad jurídica, las infracciones al principio de juridicidad no siempre acarrean la nulidad del acto irregular, pues esa sanción no puede afectar a los terceros de buena fe que actuaron con el convencimiento que el acto administrativo se encontraba ajustado a derecho ${ }^{76}$. Por lo tanto, la invalidación de los actos irregulares tiene como límite aquellas situaciones jurídicas consolidadas sobre la base de la confianza de los particulares en la actuación administrativa, la que no procede alterar, en resguardo del principio de seguridad jurídica, de manera que las consecuencias de aquéllas no pueden afectar a terceros

\footnotetext{
72 Esta primera etapa aparece en el trabajo de Sото KLoss 1988, 157-167, posteriormente publicado en Sото KLoss 1996, 194-211, tendencia iniciada por la jurisprudencia de Contraloría desde 1969 y, luego, en diversos pronunciamientos de la Corte Suprema desde 1981.

73 Dictamen N ${ }^{\circ} 16.506$, de 1971.

74 Sото KLoss 1988, 157-167.

75 Dictamen No 44.492, de 2000.

76 Dictamen $N^{\circ} 31.636$, de 2001. En el mismo sentido, véase los dictámenes $N^{\circ s} 12.272$, de 2002, y 16.238, de 2007.
} 
que adquirieron derechos de buena fe al amparo de las mismas ${ }^{77}$. De esta manera, la autoridad puede negarse a invalidar un acto administrativo, no obstante haber sido irregularmente otorgado, en la medida que haya generado situaciones jurídicas consolidadas de buena fe, sobre todo si no se advierte antecedente alguno del que aparezca que los titulares actuaron de mala fe o a sabiendas de la irregularidad que afectaba a tales actos ${ }^{78}$. Asimismo, el ejercicio de la potestad invalidatoria debe considerar la situación de hecho existente, por ejemplo, si se trata de un permiso cuyas obras ya se encuentran en ejecución o se trata de construcciones en proceso de recepción final ${ }^{79}$. Así, la doctrina de la confianza legítima y la buena fe se consolidó en la jurisprudencia relativa a los actos administrativos urbanísticos, a partir del cual se proyectó al Derecho administrativo general ${ }^{80}$.

No obstante, esta tendencia comenzó un lento declive a partir del año 2016, hasta prácticamente desaparecer en los temas urbanísticos y tener un alcance muy restrictivo en otros ámbitos ${ }^{81}$. No resuelta sencillo encontrar una respuesta a este cambio de criterio, pero si existen elementos que nos permiten sacar algunas conclusiones relevantes. En primer lugar, la jurisprudencia de la Corte Suprema ha sido categórica en señalar que la Contraloría no puede dar una orden perentoria a los órganos y servicios públicos respecto de la invalidación de actos administrativos, reconociendo una mayor deferencia a la decisión que debe adoptar la Administración activa sobre la materia ${ }^{82}$. Así, la Contraloría solo puede hacer una "suerte" de invitación a iniciar un procedimiento de invalidación, más no pronunciarse sobre el fondo ${ }^{83}$. A su vez, la

77 Dictámenes Nos 53.290 , de 2004; 8.630, de 2007; 49.531 y 2.965 , de 2008; 8.221 y 35.681 , de $2009 ; 32.639$ y 77.184 , ambos de $2010 ; 1.088,28.097$ y 73.224 , todos de $2011 ; 61.211$, de $2012 ; 62.168$, de 2013, y 12.501 , de 2016, entre otros. En particular, sobre este último principio la jurisprudencia administrativa ha señalado que el reconocimiento de la buena fe, como sustento básico de las relaciones jurídicas -de derecho público o privado- constituye la aplicación directa de los principios generales del derecho, de tal manera que no se requiere de una consagración legal expresa para que se pueda recurrir a él a los efectos de que la Administración decida acerca de la forma de proceder en situaciones como la invalidación de permisos (Dictamen N 16.238 , de 2007). Además, de acuerdo con el artículo 707 del Código Civil, la buena fe se presume, excepto en los casos en que la ley establece la presunción contraria. En todos los otros, la mala fe deberá probarse. Por consiguiente, es la eventual mala fe de los particulares que solicitan permisos de edificación, la que deberá ser acreditada por quien pretenda alegarla, siendo las DOM, a quienes corresponde ponderar los supuestos de hecho relacionados con los actos irregulares que haya emitido y con los efectos que los mismos han producido (Dictamen $\mathrm{N}^{\circ} 12.500$, de 2002).

78 Dictamen $N^{\circ} 16.238$, de 2007.

79 En este sentido véase el Dictamen N²9.192, de 2006.

80 Boettiger 2009, 309-326. Sobre el principio de buena fe en el Derecho administrativo en general, véase GonZALEZ 2004.

81 Dictamen $N^{\circ} 7.508$, de 2018. También se ha mantenido respecto del régimen de los funcionarios, como en los dictámenes Nos 13.720, de 2018 y 9.740, de 2019.

${ }^{82}$ Corte Suprema Rol No 47.610-2016. En el mismo sentido, sentencias Roles Nos 274-2010; 5815-2011 y $11.216-2011$.

${ }_{83}$ Así se puede apreciar en el Dictamen № 89.856, de 2016, que señala: "resulta necesario que esa entidad edilicia verifique que dicho permiso se conforme a lo precedentemente expuesto y, de ser procedente, adopte las providencias que en derecho correspondan a fin de corregir las 
propia Contraloría ha reconocido esta deferencia, al aceptar que las consideraciones sobre buena fe y confianza legítima pueden ser fundamentos para que la autoridad titular de la potestad invalidatoria decida no hacerlo por razones fundadas ${ }^{84}$. En este sentido, es posible entender que la Contraloría puede instruir la adopción de medidas para el restablecimiento de la legalidad, pero no puede anticipar un juicio de fondo respecto de la invalidación, ya sea ordenando dejar sin efecto un acto administrativo o imponer límites, como sería la confianza legítima o la buena fe de los terceros.

Por su parte, la situación ha sido distinta respecto de la jurisprudencia de la Corte Suprema. En efecto, durante largo tiempo nuestro máximo Tribunal sostuvo de forma reiterada que uno de los límites de los efectos de la declaración de nulidad de un acto administrativo lo constituía el principio de confianza legítima ${ }^{85}$. Sin embargo, en el año 2017 afirmó de forma categórica que de "un acto administrativo ilegal no puede generar un derecho adquirido para el solicitante" 86 , sin hacer distinción alguna respecto de la posición en que se encontraba el destinario del acto y de las deficiencias en el actuar de la Administración.

Es nuestra opinión, estos cambios de criterios generan una natural preocupación, pues este principio no solo encuentra su origen en la jurisprudencia, sino que también emana de diversas normas administrativas hacen aplicación del mismo ${ }^{87}$. Además, no parece razonable que los errores en que incurra la Administración dejen en total desprotección a personas que han obrado bajo la convicción de que el actuar de la autoridad ha sido legítimo.

No cabe duda de que los alcances y la aplicación del principio de confianza legítima han dado lugar a una importante discusión respecto de su sentido y función, al punto que se puede sostener una natural "desconfianza" por la ausencia de un real consenso sobre su existencia y alcance, pues

irregularidades que pudiesen constatarse respecto de aquel, teniendo presente lo dispuesto en el artículo 53 de la ley $\mathrm{N}^{\circ}$ 19.880, sobre la invalidación administrativa de los actos irregulares". En la misma línea los dictámenes $N^{\circ s} 43.367$ y 44.959, de 2017, y 27.918, de 2018, respecto de los casos de permisos otorgados en la comuna de Estación Central, conocidos como "guetos verticales".

84 Dictamen N $N^{\circ}$ 7.992, de 2017, en el cual se señala que "[...] Enseguida, y en ese contexto, teniendo presente que la DOM llevó a cabo el procedimiento de invalidación respecto de la referida resolución $N^{\circ} 47$, al término del cual emitió la nombrada resolución $N^{\circ} 71$, y que en los considerandos de esta última desarrolla latamente los motivos por los cuales arribó a la determinación de no dar lugar a la invalidación, entre los que se encuentran que no habría antecedentes en el expediente que permitieran establecer la mala fe del titular del anteproyecto y que existirían derechos adquiridos en su favor -consistentes en que el anteproyecto produce el efecto de mantener la vigencia de las condiciones urbanísticas con las cuales fue aprobado-, todo lo cual aparece suficientemente fundado [...].

85 Corte Suprema Rol N 1123-2005.

86 Corte Suprema Rol No 15561-2017.

87 Así sucede en el Derecho administrativo general con la figura del funcionario de hecho (artículo 63 de la Ley $N^{\circ} 18.575$ y 16 de la Ley $N^{\circ} 18.834$, sobre Estatuto Administrativo) y en sectores específicos, como ocurre en materia tributaria (artículos 8 bis $N^{\circ} 19$ y 26 del Código Tributario). 
no permite vislumbrar alguna diferencia sustantiva respecto del clásico principio de buena $\mathrm{fe}^{88}$. Por otra parte, en su origen este principio fue propuesto como una alternativa a la responsabilidad patrimonial que pudiera generar la actuación de los órganos administrativos, producto de una actuación ilegal que creaba las condiciones en los particulares para entender que se estaba obrando de forma legítima ${ }^{89}$. Sin embargo, ahora que la jurisprudencia tiende a separar la ilegalidad como base de un factor de atribución de responsabilidad $^{90}$, se ha aprovechado la oportunidad para sostener un respeto a ultranza de la legalidad objetiva, soslayando toda consideración en relación con la conducta de la Administración, así como las expectativas y condiciones que ha generado en terceros de buena fe, dejándola totalmente inmune frente a la ilegalidad cometida y el perjuicio causado ${ }^{91}$.

Por tal razón, las soluciones no debieran ser tan radicales, llevando a enfrentar el problema entre legalidad subjetiva y protección de derechos adquiridos, unida a una presunción de buena fe. Así, es posible valorar en estos casos situaciones en donde el perjuicio es evidente frente a los errores cometidos por la Administración, dejando margen para reconocer la buena fe del propietario, como en los supuestos en que la construcción ya haya comenzado o se encuentre finalizada. En ambos casos, se ha reconocido una limitación a los efectos de la nulidad de un permiso, tanto en el derecho comparado ${ }^{92}$ como en nuestra jurisprudencia administrativa ${ }^{93}$.

\section{La invalidación del permiso}

Como se ha señalado, la invalidación es una forma de extinción de los actos administrativos por razones de legalidad y cuyo pronunciamiento se encuentra entregado a la propia autoridad que dictó el acto viciado. Ahora bien, no cabe duda de que respecto de los permisos de construcción, es donde se

\footnotetext{
88 Con toda razón Santiago Muñoz Machado habla de los defectos en la construcción técnicas de este principio y de la difícil predicción en su aplicación, como también esta sucediendo en nuestro país. Muñoz Machado (2016), 149.

89 Así la Contraloría sostuvo para justificar el límite a la invalidación que "[...] aplicar la invalidación a este supuesto, podría comprometer la responsabilidad civil extracontractual del órgano administrativo que emitió el acto irregular, pues dicho actuar por ser viciado y ocasionar un daño, configuraría una especie de mal funcionamiento del servicio que haría procedente el pago de una indemnización". En este caso el conflicto fue resuelto en favor de conservar la vigencia del acto ilegal, no solo sobre la base de la buena del destinatario, sino también por las eventuales indemnizaciones que se debería pagar. Así, se sostenía que "[...] a nulidad de Derecho Público se justifica en la medida que ella se aplica para no originar situaciones más graves que las que se pretenden evitar con su vigencia". Véase dictamen N44.492, de 2000. Por su parte, no debe confundir esta situación respecto de los casos en que se han reconocido la responsabilidad del Estado por cambios normativos, sobre la base de la confianza legitima. Véase García de Enterría (2002) y Muñoz Machado (2016).

90 VALDIVIA 2016, 477-508.

91 Letelier (2014).

92 Véase CASSAgne (2012), 422 y Forsthoff (1954), 220, citando la opinión general de la doctrina alemana (W. Jellinek, Fleiner, Shoen, Ipsen, Fischers-Baltz y Scholz).

93 Dictamen $N^{\circ} 29.192$, de 2006.
} 
han planteado los aspectos más interesantes respecto de esta figura, como es el problema de los efectos que produce respecto de terceros y que hemos analizado en el apartado anterior.

En esta parte, nos corresponde dar cuenta de dos aspectos muy concretos. Uno el relativo a la autoridad competente para invalidar un permiso y el otro respecto del plazo para ejercer esta potestad.

En primer término, se ha discutido la autoridad que puede ejercer esta potestad. El artículo 53 de la LBPA dispone que "La autoridad administrativa podrá, de oficio o a petición de parte, invalidar los actos contrarios a derecho". Conforme al tenor de esta norma, la autoridad titular de la potestad invalidatoria es aquella que ha dictado el acto cuya invalidación se pretende o, dicho, en otros términos, tiene la potestad para dictar el acto invalidado, porque -como bien se ha dicho- se trata de una "atribución doméstica para corregir la ilegalidad de los actos administrativos" 14 . De esta forma, corresponde al Director de Obras Municipales ejercer dicha atribución, no siendo posible que dicha potestad sea ejercida por otra autoridad, ni siquiera el superior jerárquico es competente para aquello, tal como lo ha sostenido la Corte Suprema ${ }^{95}$ y Contraloría ${ }^{96}$.

En segundo lugar, nos encontramos con el problema del plazo. La ley dispone que dicha potestad se debe ejercer dentro del plazo de dos años contados desde la notificación o publicación del acto97. En este caso, la jurisprudencia ha entendido que se trata de un plazo de caducidad, por lo tanto, trascurrido dicho término no resulta admisible la invalidación en sede administrativa ${ }^{98}$, por lo que no se ajustaría a derecho el acto que dé inicio a un procedimiento de invalidación habiendo transcurrido con creces el referido plazo ${ }^{99}$, dado que esta potestad solo procede en la medida que se efectúe dentro de los dos años contados desde la notificación o publicación del acto $^{100}$. Además, se trata de un plazo que no se interrumpe ni suspende por la interposición de reclamos durante su vigencia ${ }^{101}$.

94 CoRdero 2014.

95 Corte Suprema Rol N 7728-2013.

96 Dictámenes Nos 53.290, de 2004, 53.875, de 2009 y 56.880, de 2011, entre otros.

97 En efecto, según lo ha sostenido la jurisprudencia administrativa "[...] los interesados en que la administración invalide un acto que estiman contrario a derecho, deben requerirlo en sede administrativa en el plazo de dos años contados de la publicación o notificación del mismo", en Dictamen $\mathrm{N}^{\circ} 3.587$, de 2007.

98 Dictamen $N^{\circ}$ 65.936, de 2012.

99 Dictamen $N^{\circ}$ 53.352, de 2015.

100 Al efecto, véase Dictámenes N³5.681, de 2009, 77.184, de 2010, 1.088 y 28.097, ambos de 2011.

101 Dictámenes $N^{\circ} 35.486$ y 41.126, ambos de 2017, entre otros. 


\section{La caducidad del permiso}

La caducidad es una institución transversal a todo el ordenamiento jurídico y que tiene particular aplicación en el ámbito del Derecho administrativo, aunque bajo su denominación se comprenden figuras diversas ${ }^{102}$.

Así, es posible distinguir entre lo que se conoce como caducidad-plazo, que tiene por objeto la consolidación de situaciones jurídicas en el más breve tiempo, ya sea para el ejercicio de acciones, derechos o potestades administrativas, estando estrechamente vinculada con la figura de la preclusión o los plazos fatales ${ }^{103}$. A su vez, también nos encontramos con la caducidad-sanción, que constituye una medida de carácter represivo frente al incumplimiento de un deber y que se traduce en la extinción de un derecho o situación jurídica. Es decir, en este caso estamos frente a un hecho que es tipificado como infracción administrativa, en donde la sanción se traduce en la extinción de una titularidad -en muchos casos de naturaleza administrativa, como una autorización, permiso o concesión- en virtud de una decisión adoptada por la Administración sujeta a un procedimiento previo ${ }^{104}$.

Las diferencias en uno y otro caso son evidentes, ya que mientras la caducidad-plazo opera por el solo ministerio de la ley y basta solo constatar el transcurso del plazo; en el caso de la caducidad-sanción se requiere necesariamente de un pronunciamiento de la Administración para determinar el incumplimiento en que ha incurrido una persona, sujeto a un procedimiento previo en el cual se deben respetar las garantías del debido proceso y para determinar si se está ante una conducta culpable.

Respecto del permiso de edificación la legislación urbanística ha establecido un plazo fatal o de caducidad. En efecto, la LGUC dispone que la vigencia, caducidad y prórroga de un permiso, como asimismo los efectos derivados de una paralización de obras o la ejecución de una obra sin permiso, se sujetarán a las normas que señale la OGUC ${ }^{105}$. A su vez, dicho cuerpo reglamentario establece que:

“El permiso caducará automáticamente a los tres años de concedido si no se hubieren iniciado las obras correspondientes o si éstas hubieren permanecido paralizadas durante el mismo lapso. Una obra se entenderá iniciada una vez realizados los trazados y comenzadas las excavaciones contempladas en los planos del proyecto"106.

\footnotetext{
102 FLORES 2017, 225-249.

103 A pesar de que se sostiene que sería una denominación polisémica, lo cierto es que está estrechamente unida al plazo fatal (véase CORDERo 2015, 317), salvo en el caso que se establece como una sanción, para la extinción de determinados derechos o situaciones jurídicas previo incumplimiento de determinados deberes y declaración de la autoridad administrativa.

104 Rodríguez-Arana, 1993, 15 y Madariaga, 1993, 10.

105 Artículo 120 de la LGUC.

106 Artículo 1.4.17. de la OGUC.
} 
La imposición de esta figura al permiso de construcción se entiende en la búsqueda de un justo equilibrio entre el diseño y formulación de una política urbana y los derechos adquiridos. En efecto, los instrumentos de planificación territorial establecen las condiciones urbanísticas a las cuales deben sujetarse los propietarios al momento de ejercer el ius aedificandi. Sin embargo, se trata de normas que están sujetas a constantes modificaciones y cambios, por lo que su mantenimiento mediante el otorgamiento del permiso supone, al mismo tiempo, la carga que se impone al propietario en orden a ejecutar las obras dentro de plazo, so pena de que dicha autorización se extinguirá con el transcurso del tiempo y, en tal supuesto, el derecho a edificar deberá sujetarse a las nuevas normas urbanísticas que surjan de la modificación o la dictación de un nuevo instrumento de planificación.

Conforme a la normativa urbanística, en este caso no cabe duda que estamos ante una caducidad-plazo, pues la propia norma indica que opera de forma "automática". Esto significa que se extingue de forma irrevocable el derecho para edificar conforme a las normas urbanísticas vigentes al momento del otorgamiento del permiso. En todo caso es importante precisar que la caducidad del permiso no afecta la titularidad sobre el derecho de propiedad que se tiene sobre el suelo, pero si pueda significar un cambio en las condiciones urbanísticas previstas en los anteriores instrumentos de planificación y, por tanto, del contenido material del derecho a edificar contenidos en ellos.

Por su parte, para el computo de este plazo existen dos supuestos que marcan su el día a quo: a) el inicio de las obras, y b) la paralización de las mismas. A su vez, se entiende que tiene lugar el inicio de las obras una vez realizados los trazados y comenzadas las excavaciones contempladas en los planos del proyecto.

A este respecto la Contraloría ha señalado que, cumplidos los supuestos pertinentes, la caducidad de los permisos opera de manera automática, sin necesidad de un acto administrativo que la establezca, pero aquello no exime del deber que le asiste a la DOM, en orden a resolver, de manera precisa, la problemática que ha sido sometida a su conocimiento, conforme al principio conclusivo, consagrado en el artículo $8^{\circ}$ de la LBPA ${ }^{107}$. A su vez, se ha insistido en que la acreditación del inicio de las obras y su realización es un elemento de carácter material que requiere ser probado, no siendo suficiente como prueba los actos formales y de carácter administrativo. Así, se ha señalado que la emisión de actos administrativos tales como aprobación de nuevos propietarios, de modificaciones y de subdivisiones no pueden constituir un antecedente suficiente para definir la concurrencia de un supuesto que dice relación con un aspecto material, vinculado a la ejecución de las obras ${ }^{108}$.

107 Dictámenes Nos 35.166, de 2010; 40.981, 51.178 y 73.004, todos de 2015.

108 Dictámenes Nos 95.979, de 2014 (ratificado y complementado por el dictamen $N^{\circ} 40.981$, de 2015); y 51.178, de 2015. 
La Corte Suprema ha ido un poco más lejos, y ha señalado que el acto administrativo que se pronuncia sobre la caducidad es una certificación o constancia, pues la autoridad solo se limita a constatar el plazo contemplado en el artículo 1.4.17 de la OGUC. Aún más, se afirma que esta resolución no requiere de un procedimiento administrativo previo para establecer la caducidad, pues opera automáticamente o de pleno derecho. Por tal razón, además, no estaría sujeto a las garantías del debido proceso administrativo "toda vez que no existe un procedimiento para declarar la caducidad, en el que la actora pudiera hacer efectiva defensas, sino que aquella solo es constatada por la autoridad"109. Por nuestra parte, no compartimos dicha conclusión, porque es evidente que la declaración de caducidad da lugar a un acto desfavorable y que exige de una serie de antecedentes que solo se encuentran en poder del titular del proyecto, quien tiene un interés manifiesto que exige su intervención en el procedimiento administrativo, considerando las normas que garantizan el debido proceso administrativo (artículos 10, 17 y 21 LBPA).

Por último, debemos también comentar dos puntos relevantes en esta materia y que han dado también a una jurisprudencia de interés.

En primer término, se encuentran los proyectos desarrollados por etapas, pues el inicio de las obras puede comprender la etapa inicial o el conjunto de todas ellas. En tal sentido, la Contraloría ha señalado que en estos casos es condición necesaria realizar el trazado de todo el terreno que den cuenta, al menos de los ejes de pilares, muros y fundaciones ${ }^{110}$. Sin embargo, este criterio fue revisado por la Corte Suprema, que sostuvo que para suspender el plazo de caducidad en un proyecto de construcción por etapas es suficiente que se hubieren iniciado las obras en solo una de las torres proyectadas, y no respecto de todo el proyecto inmobiliario, de acuerdo con lo preceptuado en el artículo 1.4.7 de la OGUC ${ }^{111}$.

En segundo lugar, se ha discutido el problema del plazo de caducidad y su posible suspensión. En efecto, desde el punto de vista dogmático se ha sostenido que, dada su naturaleza y función, el plazo de caducidad no admite suspensión ni interrupción. Sin embargo, en muchos casos la dilación en el inicio de las obras no es imputable al titular del proyecto, sino que a actos que provienen de la propia autoridad administrativa o judicial. Es así como la Corte Suprema ha sostenido que, no siendo atribuible a la reclamante la demora en la ejecución del proyecto, los hechos que suponen la paralización

\footnotetext{
109 Corte Suprema Rol N²9.946-2018, considerando $13^{\circ}$. En la misma línea, Corte Suprema Rol $N^{\circ} 37.170-2017$, considerando $21^{\circ}$.

110 Dictamen N²5.188-2018. En un sentido similar, Sentencia de Corte Suprema Rol N 13.2052018: "Resulta indispensable que el trazado se haya efectuado sobre el suelo tal y como aparezca en los planos, de manera que la realización de algunas marcas o el señalamiento de algunos hitos resulta del todo insuficiente para satisfacer la exigencia de la mencionada norma".

111 Corte Suprema Rol No 29.614-2019.
} 
por acto de autoridad no se encuadran en la caducidad ${ }^{112}$, es decir, se admite su suspensión. En este caso, la jurisprudencia en alguna medida muta la naturaleza de esta figura, pues la considera como una sanción que se produce por un hecho que no es atribuible al titular del proyecto, por lo que no es posible sostener respecto de su conducta u omisión un juicio de reproche. En nuestra opinión, este es el criterio que debiera orientar la institución de la caducidad y que le da sentido a su existencia, es decir, pasar desde una caducidad-plazo a una caducidad-sanción, pues esta institución debe representar un mecanismo de disuasión que tenga por objeto castigar al titular de proyecto que no ha sido diligente o, en su caso, no ha materializado un proyecto, no asumiendo las cargas urbanísticas que se le exigen. Por ahora, estamos frente a una figura de naturaleza mixta, en donde cumple la función de una caducidad plazo, que opera por el solo ministerio de la ley, salvo en los casos que el inicio o paralización de la obra no sea imputable, por acto de autoridad, al titular del proyecto. A su vez, y como hemos indicado, necesariamente debe existir un procedimiento previo para declarar la caducidad, en concordancia con el principio del debido procedimiento administrativo que ha reconocido ampliamente la jurisprudencia constitucional, haciendo aplicación de lo dispuesto en el artículo $19 \mathrm{~N}^{\circ} 3$ de la Constitución ${ }^{113}$.

\section{Los medios de impugnación}

El último de los aspectos en que se ha coordinado el Derecho administrativo general con el Derecho urbanístico ha sido respecto del régimen de impugnación y el contencioso administrativo, al punto de lograr una plena integración que lleva a sostener que los medios de impugnación de un permiso de construcción siguen, en su clasificación, el criterio general de impugnación de los actos administrativos, distinguiendo entre los recursos administrativos y jurisdiccionales.

La ausencia de una jurisdicción administrativa ha incidido en la precaria construcción del Derecho administrativo en Chile durante largas décadas, hasta que no se perfila con toda nitidez el reconocimiento del control judicial pleno respecto de los actos de la Administración y el diseño de un conjunto de acciones administrativas destinadas a velar por la legalidad de su actuar, la responsabilidad patrimonial y el respeto de los derechos de las personas frente al ejercicio abusivo del poder público.

En los sistemas jurídicos occidentales, la técnica primordial de garantía ha estado y está constituida por el control jurisdiccional, esto es, el ejercido

\footnotetext{
112 Corte Suprema Rol No 16.238-2019, considerando $15^{\circ}$. Es posible encontrar precedentes en el Dictamen N 84.791, de 2015, de Contraloría, así como en la sentencia de la Corte Suprema. Rol N 6969-2012, en la cual se señala que: "El plazo de caducidad no puede incluir el tiempo en que las obras permanecieron paralizados por orden de la autoridad edilicia, esto es, entre la fecha en que se dictan los respectivos actos revocatorios y aquella en que se dicta el cúmplase en los reclamos de ilegalidad [...]".

113 Tribunal Constitucional Rol $N^{\circ} 437$, considerando $17^{\circ}$.
} 
por los órganos integrantes del Poder Judicial. Nuestro texto constitucional consagra este principio en dos capitales preceptos:

a) De una parte, en su vertiente objetiva, el principio se consagra en el artículo 76, al disponer que "la facultad de conocer de las causas civiles y criminales, de resolverlas y de hacer ejecutar lo juzgado, pertenece exclusivamente a los tribunales establecidos por la ley"; y que en el ámbito específico de la Administración se complementa por lo dispuesto en el artículo 38 inciso segundo en los términos siguientes: "Cualquier persona que sea lesionada en sus derechos por la Administración del Estado, de sus organismos o de las municipalidades, podrá reclamar ante los tribunales que determine la ley, sin perjuicio de la responsabilidad que pudiere afectar al funcionario que hubiere causado el daño".

b) De otra, la vertiente subjetiva de este sometimiento al control judicial viene establecida en el artículo $19 \mathrm{~N}^{\circ} 3$, que lo concibe como un derecho fundamental, al disponer que se asegura a todas las personas: "La igual protección de la ley en el ejercicio de sus derechos. Toda persona tiene derecho a defensa jurídica en la forma que la ley señale y ninguna autoridad o individuo podrá impedir, restringir o perturbar la debida intervención del letrado si hubiere sido requerida".

Esto debe ser complementado con el sistema de recursos administrativos que establece nuestro ordenamiento, que con carácter general reconoce recursos ordinarios (reposición y jerárquico, artículo 59 de la LBPA); recurso extraordinario de revisión (artículo 60 de la LBPA), y recursos administrativos regulados por leyes especiales, junto a un sistema general de coordinación entre los recursos administrativos y jurisdiccionales que se construye sobre una opción en favor del recurrente, aunque evitando las vías paralelas (artículo 54 de la LBPA).

En materia urbanística tenemos un sistema especial de recursos administrativos y judiciales, contenido en la LGUC y la LOCM, sin perjuicio de la aplicación del régimen general de coordinación previsto en el ya citado artículo 54.

En efecto, en sede administrativa la LGUC establece un recurso especial para impugnar los actos del DOM ante la SEREMI de Vivienda y Urbanismo, conforme lo establece el artículo 118 de la LGUC. De acuerdo con la jurisprudencia, estamos ante un recurso administrativo especial de tutela, considerando que no existe entre la DOM y la SEREMI una relación de subordinación o dependencia ${ }^{114}$. Sin embargo, hasta hace poco tiempo no había claridad respecto de la vía jurisdiccional que se debía seguir, ya sea mediante la acción de nulidad de derecho público o el contencioso especial contenido en el artículo 151 de la LOCM.

En este caso, la Corte Suprema ha aplicado un criterio general respecto de la procedencia de la acción de nulidad de derecho público, sosteniendo

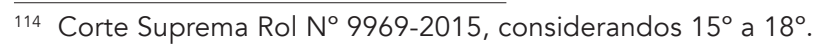


que la existencia de un contencioso administrativo especial inhibe el ejercicio de dicha acción ${ }^{115}$, es decir, al existir vías específicas de reclamación contra el acto impugnado, deben prevalecer dichos procedimientos antes que el ejercicio de la acción genérica de nulidad de derecho público, siendo plenamente aplicable en estos caso, al existir el reclamo de ilegalidad municipal ${ }^{116}$.

Luego, en sede jurisdiccional se ha reconocido la compatibilidad que tiene la norma del artículo 118 de la LGUC con el reclamo de ilegalidad municipal previsto en el artículo 151 de la Ley N¹8.695, Orgánica Constitucional de Municipalidades ${ }^{117}$. Así, la Corte Suprema ha señalado que:

"[...] un correcto análisis normativo permite concluir que los actos del Director de Obras son reclamables por una doble vía: a) Administrativa ante el Seremi de Vivienda y Urbanismo respectivo a través del ejercicio de la acción de los artículos 12 y 118 de la Ley General de Urbanismo y Construcciones; y b) Jurisdiccional, que se inicia con una etapa administrativa previa ante el Alcalde y culmina con la presentación del reclamo en sede judicial conforme lo establece el artículo 151 de la Ley $\mathrm{N}^{\circ}$ 18.695. [...] Así, el afectado por lo resuelto por un Director de Obras se enfrenta a la posibilidad de iniciar dos reclamos, no estando obligado a optar por alguno de ellos, pues se trata de dos acciones, una claramente jurisdiccional, que corresponde a aquella intentada en autos, y otra administrativa, sin que una de ellas excluya a la otra, por lo que ninguna de las dos autoridades puede negarse a conocer de la que se dedujo, pudiendo incluso ambas resolver lo que sea pertinente en derecho, sin perjuicio de lo dispuesto en el artículo 54 de la Ley $N^{\circ} 19.880$ sobre Procedimiento administrativo"118.

En definitiva, el régimen de impugnación en materia urbanística se ha adaptado a las exigencias constitucionales de control y tutela judicial efectiva, mediante una interpretación armónica que ha hecho la jurisprudencia para coordinar los medios de impugnación administrativos previstos en la LGUC, con la legislación municipal y la legislación administrativa general, estableciendo un sistema coherente y ordenado.

\section{Conclusiones}

El desarrollo del trabajo nos permite concluir que siendo el permiso de construcción una institución propia y característica del Derecho urbanístico, su análisis y aplicación práctica aporta elementos de interés al Derecho administrativo general, confiriéndole una notable dinámica a la teoría del acto administrativo. Además, nos permite poner a prueba las formulaciones y

115 Corte Suprema Roles No 5376-2009, 8246-2009, 7750-2011 y 8742-2014.

116 Corte Suprema Rol No34.277-2017, considerando $10^{\circ}$. También se ha dicho en los Roles $\mathrm{N}^{\circ} 3.412-2015, \mathrm{~N}^{\circ} 23.587-2015, \mathrm{~N}^{\circ} 17.405-2016$ y No 35.585- 2016.

117 Corte Suprema Rol No 1669-2015.

118 Corte Suprema Rol No 9969-2015, considerando $15^{\circ}$. 
conceptos generales de la doctrina, planteando cuestionamientos no menores a figuras tan centrales como la autorización administrativa y la supuesta existencia de un derecho preexistente, frente a la patrimonialización de situaciones jurídicas que el acto implica en sí mismo.

Por otra parte, el peso de la legalidad urbanística y la configuración del contenido material del derecho de propiedad sobre el suelo, no hacen sino reforzar la necesidad de contar con un análisis del permiso de construcción que permita sistematizarlo y comprenderlo dogmáticamente dada la importancia vital que tiene como el último eslabón en el tracto de decisiones públicas que debe adoptar la autoridad respecto de la ordenación racional del suelo y de su materialización efectiva.

También se debe reconocer que algunos de los problemas estructurales de nuestro sistema también llegan a este nivel, como ocurre con la justicia administrativa, pero que en materia urbanística ha encontrado soluciones interesantes que, en buena medida, han superado la superposición de autoridades que deben emitir actos de adjudicación en estas materias.

En definitiva, queda demostrado que el permiso de construcción como acto administrativo ha sido una de las instituciones que más ha enriquecido el Derecho administrativo general en la formulación de criterios de solución en las relaciones jurídico-administrativas, así como de integración de vacíos, lo que necesariamente se ha proyectado en las autoridades, funcionarios, jueces y juristas que aplican de forma cotidiana la legislación administrativa general.

\section{Bibliografía citada}

Anschuetz, G. (1929). Die Verfassung des Deutschen Reichs vom 11. August 1919: ein Kommentar fuer Wissenschaft und Praxis (10 edición). Stilke.

AtienZA, M. (2005). Las razones del derecho. Teoría de la argumentación jurídica. UNAM.

Rodriguez-Arana, J. La caducidad en el Derecho Administrativo Español, Montecorvo.

Berthelmy, H. (1913). Traite elementaire de Droit administratif (7 $7^{a}$ edición). Librairie Nouvelle de Droit et Jurisprudence.

Boettiger, Camila (2009). "El principio de la buena fe en la jurisprudencia de la Contraloría General de la República en materia urbanística". Actualidad Jurídica, 19, pp. 309-326.

Bonnard, R. (1943). Précis elementaire de Droit administratif (4 edición). Librairie Generales de Droit et de Jurisprudence.

Brahm García, E. (1992). "La propietarización de los derechos en la Alemania de entreguerras". Revista Chilena de Derecho, 19(3), 411-414.

CAMACHo, G. (2010). Tratado de Derecho Administrativo (Tomo IV). Abeledo Perrot.

CASSAGne, Juan Carlos (2012). El acto administrativo. Teoría y régimen jurídico. La Ley.

Cordero VegA, L. (29 de octubre de 2014). Recursos administrativos e invalidación. Mercurio Legal.

(2015). Lecciones de Derecho Administrativo ( $2^{\mathrm{a}}$ ed.). Thomson Reuters.

Cordero, E. (2008). "El Derecho urbanístico chileno y la garantía constitucional de la propiedad". Nomos (2), pp. 91-112.

(2015) "Naturaleza, contenido y principios del Derecho urbanístico chileno". Revista de Derecho (Coquimbo), 22 (2), 92-138.

(2017). "La formación del Derecho urbanístico chileno a partir del siglo XIX: de la legislación urbanística al Derecho urbanístico integrado". Revista de Derecho (Valdivia), 1(1), jun. 2017, 127-152. 
DesdentAdo, Eva (1999). El precario administrativo. Un estudio de las licencias, autorizaciones y concesiones en precario. Aranzadi.

DíAS DE VAldÉs, J. y ENTEICHE, N. (2015). "La estabilidad de los actos administrativos urbanísticos". Revista Actualidad Jurídica, (31), enero, 235-266.

Duguit, León (1923). Traite de Droit constitutionnel (Tomo III) (10ª ed.). Ancienne Libraririe Fontemoing \& Cia.

Figueroa Velasco, P. y Figueroa Valdés, J. (2016). Urbanismo y Construcción (2a ed.). Legal Publishing.

Flores, Juan Carlos (2017). "La caducidad de los actos administrativos". Revista de Derecho, Valdivia (XXX), N², pp. 225-249.

ForsthOFF, E. (1954). Lehrbuch des Verwaltungsrechts (4 ed.). C. Beck.

Fuentes Olmos, J. (1997). El concepto del derecho de propiedad en la jurisprudencia constitucional chilena (1981-1996). [Memoria de Prueba, Universidad Católica de Valparaíso].

García de Enterría, E. (2002). "El principio de protección de la confianza legítima como supuesto título justificativo de la responsabilidad patrimonial del Estado Legislador". Revista de Administración Pública, (159), pp.173-208.

Garcia de Enterría, E. y Fernandez, Tomás-Ramón (2008a). Curso de Derecho Administrativo, (T. 1) (14 a ed.), Thomson Civitas.

Garcia de Enterría, E. y Fernandez, Tomás-Ramón (2008b). Curso de Derecho Administrativo, (T. 2) (1 $1^{\text {a ed.) }}$, Thomson Civitas.

García de Enterría, E. y Parejo Alfonso, L. (1981). Lecciones de Derecho urbanístico. Civitas.

GarRIDo Falla, F. (1959). "Los medios de policía y la teoría de las sanciones administrativa". Revista de Administración Pública, (28), 25-20.

(2002). Tratado de Derecho Administrativo (Vol. II) (11 a ed.). Tecnos.

GIESE, F. (1921). Die Verfassung des Deutschen Reiches vom 11. August 1919: Taschenausgabe fuer Studium und Praxis (6 ed.). Heymann.

GuZMÁn BRITO, A. (1995). Las cosas incorporales en la doctrina y en el derecho positivo. Editorial Jurídica de Chile.

González Pérez, Jesús (1989). Los derechos reales administrativos. Civitas.

(2004). El principio general de la buena fe en el derecho administrativo. Civitas.

Hauriou, M. (1908). Arrét del Conseil dÊta. Ministerio de Comercio con Ferrocarriles de Orleans. Recueil général des lois et des arrêts: en matière civile, criminelle, commerciale, administrative et de droit public, 01 janvier 1908, III partie, 65-67.

HOFACKER, W. (1926). Grundrechte und Grundpflichten der Deutschen. Kolhammer.

Hunter Ampuero, I. (2014). "Reclamo de ilegalidad municipal en la jurisprudencia: caos interpretativo y criterios dudosos". Revista Derecho (Valdivia), 27(2), 191-215.

Letelier, Raúl (2014). "Contra la confianza legítima como límite a la invalidación de actos administrativos". Revista Chilena de Derecho, (41) N², pp. 609-634.

Madariaga, M. (1993). Seguridad jurídica y administración pública en el siglo XXI (2a ed.). Editorial Jurídica de Chile.

Muñoz Machado, Santiago (2016). "Regulación y confianza legítima". Revista de Administración Pública, (200), pp. 141-172.

Papier, H. J. (2009). Die Eigentumsgarantie des Art. 14 Abs. 1 Satz 1. En T. Maunz; G. Dürig y R. Herzog, Grundgesetz Komentar (53a ed.) (pp. 11-17). Beck.

Parada, R. (2013). Derecho Administrativo. Bienes públicos. Derecho urbanístico. Open (Tomo III) $\left(14^{\mathrm{a}}\right.$ ed.).

PAREJo, L. (coord.) (2008). Manual de Derecho Administrativo (T. II) (5 edición). Ariel.

PAREJo, L. (2010). Derecho Administrativo (10 ed.). Tirant Lo Blanch.

PAREJo, L. (1996). Algunas reflexiones sobre las cuestiones básicas del régimen jurídico del subsuelo. Ciudad y Territorio (109), pp. 387-402.

PAREJo, L. (2017). "La ordenación territorial y urbanística en el período 2007-2017". Práctica Urbanística (146), pp. 1-23.

Pierry Arrau, P. (2017). Derecho Administrativo. Obra Reunida. Ediciones Universitarias de Valparaíso. 
Poetsch-Heffter, F. (1928). Handkommentar der Reichsverfassung vom 11 August 1919. Ein Handbuch für Verfassungsrecht und Verfassung Politik. Liebmann ( $3^{\mathrm{a}}$ ed.).

RAJEVIC, E. (2004). "El permiso de construcción como acto administrativo". AAVV, Acto y procedimiento administrativo (pp. 183-208). Ediciones Universitarias de Valparaíso.

Santamaría Pastor, J. (2016). Principios de Derecho Administrativo General (T II) (4 a edición). lustel.

Sото KLoss, Eduardo (1984). "Los derechos adquiridos en el Derecho público chileno. Revista de Derecho y Jurisprudencia, 81(1), primera parte, 13-15.

(1988) "La invalidación de los actos administrativos en el Derecho chileno", en Revista Derecho y Jurisprudencia, 85 (3), pp. 157-167.

(1991). "Comentario sentencia de protección Diaz Maliqueo". Revista de Derecho y Jurisprudencia, Tomo II (2), segunda parte, sección quinta, 192-195.

(1995). Derecho administrativo. Bases fundamentales (Tomo II). Editorial Jurídica de Chile.

TRIEPEL, H. (1924). Goldbilanzverordnung und Vorzugaktien. De Gruyter.

VALDIVIA, J. (2016). "Actos administrativos y responsabilidad del Estado". J. FerRadA, J. BerMÚDEZ y O. URRUTIA, Doctrina y enseñanza del Derecho administrativo chileno: Estudios en homenaje a Pedro Pierry Arrua (pp. 477-508). Ediciones Universitarias de Valparaíso.

Valenzuela Paravic, P. (1989). Aspectos jurídicos del Permiso de Edificación Municipal [Memoria de Prueba, Universidad Católica de Valparaíso].

Valenzuela Paravic, P. (1991-1992). "Las acciones contenciosas derivadas del permiso de edificación municipal". Revista de Derecho (Valparaíso), (14), 97-124.

Vergara Blanco, A. (1991). "La propietarización de los derechos". Revista de Derecho, Valparaíso, (14), pp. 281-291.

Vergara Blanco, A. (1992). Principios y sistema del derecho minero. Estudio histórico-dogmático, Editorial Jurídica de Chile.

ZANOBINI, G. (1958). Corso di Diritto administrativo (5 $5^{a}$ ed.). Giuffrè.

\section{Normativa citada}

Decreto No 100 de 2005 [Ministerio Secretaría General de la Presidencia]. Fija el texto refundido, coordinado y sistematizado de la Constitución Política de la República de Chile. 22 de septiembre de 2005.

Decreto No 458 de 1975 [con fuerza de Ley]. Aprueba la Ley General de Urbanismo y Construcciones. 18 de diciembre de 1975. D.O. N² 29.431.

Decreto $N^{\circ} 47$ de 1992 [Ministerio de Vivienda y Urbanismo]. Fija el nuevo texto de la Ordenanza General de la Ley General de Urbanismo y Construcciones. 16 de abril de 1992.

Ley N ${ }^{\circ} 18.575$ de 1986. Ley Orgánica Constitucional de Bases Generales de la Administración del Estado. 12 de noviembre de 1986. D.O. N 32.640.

Ley N 18.695 DE 2006. Ley Orgánica Constitucional de Municipalidades. 9 de mayo de 2006. D.O. $N^{\circ} 38.523$.

Ley $N^{\circ} 18.883$ de 1989. Aprueba el Estatuto Administrativo para funcionarios municipales. 15 de diciembre de 1989. D.O. No 33.557.

Ley $N^{\circ} 19.880$ de 2003. Establece bases de los procedimientos administrativos que rigen los actos de los órganos de la Administración del Estado. 22 de mayo de 2003. D.O. $N^{\circ} 37.570$.

\section{Jurisprudencia citada}

Contraloría General de la República. Dictamen N 1.589, de 1957.

Contraloría General de la República. Dictamen N 16.506, de 1971.

Contraloría General de la República. Dictamen N 12.868, de 1981.

Contraloría General de la República. Dictamen N 1.057, de 1983.

Corte Suprema. Sala Tercera. Rol N 4.073-1998, 30 diciembre 1998. 
Contraloría General de la República. Dictamen N 47.073, de 1998.

Corte de Apelaciones de Santiago. Sala. Rol No 1.190-99, 3 agosto 1999.

Contraloría General de la República. Dictamen N 5.888, de 1999.

Corte Apelaciones de Antofagasta. Sala. Rol No 12.447, 14 agosto 1999 [confirmada por la Corte Suprema, Rol No 3.022-1999, 13 septiembre 1999].

Corte Suprema. Sala Tercera. Rol No 40-2000, 20 enero 2000.

Contraloría General de la República. Dictamen N²5.310, de 2000.

Contraloría General de la República. Dictamen N 44.492, de 2000.

Contraloría General de la República. Dictamen N³9.735, de 2000.

Contraloría General de la República. Dictamen N. 2.936, de 2001.

Contraloría General de la República. Dictamen N²7.132, de 2001.

Contraloría General de la República. Dictamen N³1.636, de 2001.

Contraloría General de la República. Dictamen N³4.252, de 2001.

Contraloría General de la República. Dictamen N³5.046, de 2001.

Contraloría General de la República. Dictamen N³5.624, de 2001.

Contraloría General de la República. Dictamen N 7.308, de 2002.

Contraloría General de la República. Dictamen N 12.500, de 2002.

Contraloría General de la República. Dictamen No 12.272, de 2002.

Corte Suprema. Sala Tercera. Rol No 3.104-2002, 24 septiembre 2003.

Contraloría General de la República. Dictamen N 18.447, de 2004.

Contraloría General de la República. Dictamen N 53.290, de 2004.

Corte Suprema. Sala Tercera. Rol N 1123-2005, 29 de diciembre de 2005.

Contraloría General de la República. Dictamen N 12.305, de 2006.

Contraloría General de la República. Dictamen N²9.192, de 2006.

Contraloría General de la República. Dictamen N³2.357, de 2006.

Contraloría General de la República. Dictamen N³3.451, de 2006.

Corte Suprema. Sala Tercera. Rol No 3.604-2005, 16 de mayo 2006.

Corte Suprema. Sala Tercera. Rol N²39-2006, 28 febrero 2006.

Tribunal Constitucional. Rol N 505-2006, 6 marzo 2007.

Tribunal Constitucional. Rol N 506-2006, 6 marzo 2007.

Tribunal Constitucional. Rol N 698-2006, 19 septiembre 2007.

Contraloría General de la República. Dictamen N³ 3.587, de 2007.

Contraloría General de la República. Dictamen N 7.201, de 2007.

Contraloría General de la República. Dictamen N 8.630, de 2007.

Contraloría General de la República. Dictamen N 16.238, de 2007.

Contraloría General de la República. Dictamen N².695, de 2008.

Contraloría General de la República. Dictamen No 13.522, de 2008.

Contraloría General de la República. Dictamen N 48.334, de 2008.

Contraloría General de la República. Dictamen N 49.531, de 2008.

Contraloría General de la República. Dictamen N 8.221, de 2009.

Contraloría General de la República. Dictamen N³5.681, de 2009.

Contraloría General de la República. Dictamen N³5.681, de 2009.

Contraloría General de la República. Dictamen N³5.681 de 2009.

Contraloría General de la República. Dictamen No 53.875, de 2009.

Contraloría General de la República. Dictamen N³2.639 de 2010.

Contraloría General de la República. Dictamen N³5.166, de 2010.

Contraloría General de la República. Dictamen N56.001, de 2010.

Contraloría General de la República. Dictamen № 77.184, de 2010.

Corte Suprema. Sala Tercera. Rol No 4383-2008, 19 mayo 2010.

Corte Suprema, Rol No 4384-2008, 19 de mayo de 2010.

Tribunal Constitucional. Rol No 1309-2010, 20 abril 2010.

Corte Suprema. Sala Tercera. Rol No 5.370-2009, 15 julio 2011.

Corte Suprema. Sala Tercera. Rol No 2.217-2009, 9 de agosto de 2011.

Corte Suprema. Sala Tercera. Rol N 5.376-2009, 12 septiembre 2011.

Corte Suprema. Sala Tercera. Rol No 7.750-2011, 7 noviembre 2011. 
Contraloría General de la República. Dictamen N 1.008, de 2011. Contraloría General de la República. Dictamen N 1.088, de 2011. Contraloría General de la República. Dictamen N²8.097, de 2011. Contraloría General de la República. Dictamen N 56.880, de 2011. Contraloría General de la República. Dictamen N 61.211, de 2012. Contraloría General de la República. Dictamen N 73.224, de 2011. Contraloría General de la República. Dictamen N 77.490, de 2011. Corte Suprema. Sala. Rol N 8.247-2009, 20 enero 2012.

Corte Suprema. Sala. Rol No 6.969-2012, 26 noviembre 2012.

Contraloría General de la República. Dictamen N³0.891, de 2012. Contraloría General de la República. Dictamen N 45.377, de 2012. Contraloría General de la República. Dictamen N 61.211, de 2012. Contraloría General de la República. Dictamen N 65.936, de 2012. Contraloría General de la República. Dictamen N 80.449, de 2012. Contraloría General de la República. Dictamen N 40.436, de 2013. Contraloría General de la República. Dictamen N 62.168, de 2013. Corte Suprema. Sala Tercera. Rol No 274-2010, 30 enero 2013. Corte Suprema. Sala Tercera. Rol No 3.918-2012, 2 mayo 2013. Corte Suprema. Sala Tercera. Rol No 9.433-2011, 29 mayo 2013 Corte Suprema. Sala Tercera. Rol N³77-2012, 18 noviembre 2013. Corte Suprema. Sala Tercera. Rol No 57-2011, 20 noviembre 2013. Corte Suprema. Sala Tercera. Rol N 7.728-2013, 20 noviembre 2013.

Corte Suprema. Sala Tercera. Rol No 11.216-2011, 10 de enero de 2013

Corte Suprema. Sala Tercera. Rol No 274-2010, 20 de enero de 2013. Corte Suprema. Sala Tercera. Rol No 5.080-2011, 14 enero 2013.

Corte Suprema. Sala Tercera. Rol N 5815-2011, 26 de marzo de 2013. Corte Suprema. Sala Tercera. Rol No 9.433-2011, 29 mayo 2013. Corte Suprema. Sala Tercera. Rol No 3.918-2012, 2 mayo 2013. Corte Suprema. Sala Tercera. Rol No 377-2012, 18 noviembre 2013. Tribunal Constitucional. Rol No 2.299-12, 29 enero 2014.

Corte Suprema. Sala Tercera. Rol N 3.078-2013, 31 enero 2014. Corte Suprema. Sala Tercera. Rol No 8.742-2014, 3 julio 2014. Corte Suprema. Sala Tercera. Rol No 16.706-2014, 10 diciembre 2014. Corte Suprema. Sala Tercera. Rol N²3.766-2014, 22 diciembre 2014. Contraloría General de la República. Dictamen N 78, de 2014. Contraloría General de la República. Dictamen No 17.344, de 2014. Contraloría General de la República. Dictamen N59.619, de 2014. Contraloría General de la República. Dictamen N 93.083, de 2014. Contraloría General de la República. Dictamen N 95.979, de 2014. Corte Suprema. Sala Tercera. Rol No 5.815-2011, 26 marzo 2015. Corte Suprema. Sala Tercera. Rol N 32.091-2014, 30 marzo 2015. Corte Suprema. Sala Tercera. Rol No 1.555-2015, 2 abril 2015. Corte Suprema. Sala Tercera. Rol No 2.614-2015, 16 junio 2015. Corte Suprema. Sala Tercera. Rol N².850-2015, 25 junio 2015. Corte Suprema. Sala Tercera. Rol No 1669-2015, 26 noviembre 2015. Contraloría General de la República. Dictamen N 16, de 2015. Contraloría General de la República. Dictamen N²1.213, de 2015. Contraloría General de la República. Dictamen N²3.573, de 2015. Contraloría General de la República. Dictamen No 40.981, de 2015. Contraloría General de la República. Dictamen N 40.981, de 2015. Contraloría General de la República. Dictamen N 46.044, de 2015. Contraloría General de la República. Dictamen N 51.178, de 2015. Contraloría General de la República. Dictamen N53.352, de 2015. Contraloría General de la República. Dictamen N 73.004, de 2015. Contraloría General de la República. Dictamen Nº 84.791, de 2015. 
Contraloría General de la República. Dictamen N 96.740, de 2015. Corte Suprema. Sala Tercera. Rol N 9.969-2015, 17 mayo 2016.

Corte Suprema. Sala Tercera. Rol No 47.610-2016, 4 de octubre de 2016. Contraloría General de la República. Dictamen N 12.501, de 2016. Contraloría General de la República. Dictamen N 12.926, de 2016. Contraloría General de la República. Dictamen № 45.217, de 2016. Contraloría General de la República. Dictamen N 89.856, de 2016. Contraloría General de la República. Dictamen N 92.304, de 2016. Contraloría General de la República. Dictamen N 7.992, de 2017. Contraloría General de la República. Dictamen N 35.486, de 2017. Contraloría General de la República. Dictamen N 41.126, de 2017. Contraloría General de la República. Dictamen N 43.367, de 2017. Contraloría General de la República. Dictamen № 44.959, de 2017. Corte Suprema. Sala Tercera. Rol N²5.784-2016, 9 mayo 2017.

Corte Suprema. Sala Tercera. Rol N 5980-2017, 18 diciembre 2017. Corte Suprema. Sala Tercera. Rol No 15561-2017, 27 diciembre 2017. Contraloría General de la República. Dictamen N 7.992, de 2017. Contraloría General de la República. Dictamen N² 25.188-2018. Contraloría General de la República. Dictamen N² 27.918, de 2018. Corte Suprema. Sala Tercera. Rol No 34.277-2017, 7 marzo 2018. Corte Suprema. Sala Tercera. Rol No 37.170-2017, 21 de junio de 2018. Corte Suprema. Sala Tercera. Rol No 13.205-2018, 30 agosto 2018. Corte Suprema. Sala Tercera. Rol No 4.163-2018, 13 enero 2020. Corte Suprema. Sala Tercera. Rol No 16.238-2019, 24 enero 2020. Corte Suprema. Sala Tercera. Rol No 29.946-2018, 15 abril 2020. Corte Suprema. Sala Tercera. Rol No 31-814-2018, 15 abril 2020. Corte Suprema. Sala Tercera. Rol No 29.614-2019, 7 agosto 2020. 